
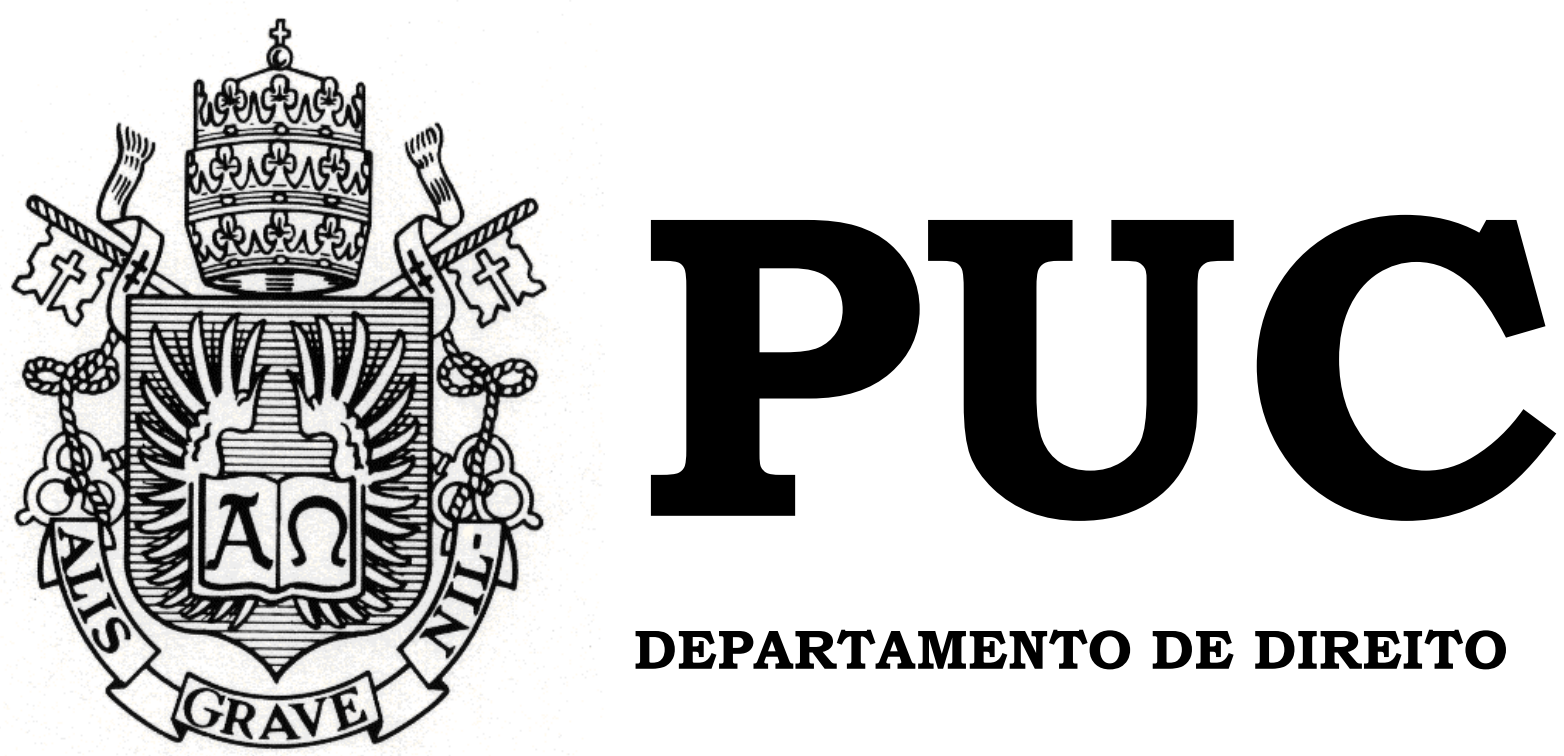

DEPARTAMENTO DE DIREITO

\title{
CLÁUSULA COMPROMISSÓRIA DE MEDIAÇÃO
}

Por

EDUARDA FRANÇA PACHÁ FERRAZ

ORIENTADOR: ALEXANDRE SERVINO ASSED

2016.2

PONTIFÍCIA UNIVERSIDADE CATÓLICA DO RIO DE JANEIRO

RUA MARQUÊS DE SÃO VICENTE, 225 - CEP 22451-900

RIO DE JANEIRO - BRASIL 


\title{
CLÁUSULA COMPROMISSÓRIA DE MEDIAÇÃO
}

por

\section{EDUARDA FRANÇA PACHÁ FERRAZ}

\author{
Monografia apresentada ao \\ Departamento de Direito da \\ Pontificia Universidade Católica do \\ Rio de Janeiro (PUC-Rio) para a \\ obtenção do Título de Bacharel em \\ Direito.
}

Orientador: Alexandre Servino Assed

2016.2 


\section{AGRADECIMENTOS}

Agradeço aos meus pais e irmão pelo amor, incentivo e apoio incondicional nessa etapa decisiva. Ao meu orientador Alexandre Assed, pelo suporte no pouco tempo que lhe coube, pelas suas correções e incentivos. Agradeço também a todos os professores da Pontifícia Universidade Católica do Rio de Janeiro que contribuíram com a minha formação acadêmica.

A todos os que me são queridos, amigos, colegas de turma e pessoas que direta ou indiretamente fizeram parte da minha formação, o meu muito obrigada. Dedico esse trabalho à minha família por todo o apoio dado ao longo do Curso de Direito. 


\section{RESUMO}

Trata-se de monografia que apresenta os aspectos relevantes trazidos com a previsão contratual da mediação por meio de cláusula compromissória, conforme disposto na nova Lei de Mediação. Essa inovação legislativa permite que os contratantes à ocasião da celebração de um negócio jurídico optem pela mediação como meio de solução de eventual controvérsia oriunda da relação obrigacional, estimulando a eleição desse método autocompositivo em franca evolução no cenário brasileiro. Nesse contexto, destaca-se a base principiológica da cláusula compromissória, que tem como princípio norteador a autonomia da vontade das partes, para depois ponderar acerca da importância e aplicabilidade desta cláusula contratual. Em seguida, são trazidos os requisitos formais e critérios que permeiam a confecção do dispositivo, bem como a possibilidade de inclusão de pacto de não litigância pelos contratantes e os efeitos de sua não observância. Por fim, aborda-se a questão controversa relativa à possibilidade de inclusão de cláusula compromissória de mediação em contratos de adesão, traçando-se assim, um paralelo com o instituto da arbitragem. Adentrando na discussão são colocadas as posições dos principais doutrinadores nacionais, bem como considerações próprias sobre o tema. Em sede de conclusão, é demonstrada a significância dessa nova possibilidade concedida pela Lei.

Palavras-Chave: Mediação; Cláusula; Contrato; Autonomia da vontade. 


\section{SUMÁRIO}

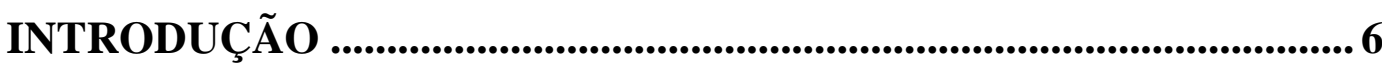

CAPÍTUlO 1 - Base Principiológica da Cláusula Compromissória de

Mediação........................................................................................................9

1.1. Princípio da Autonomia da Vontade/Protagonismo/Autoria............. 11

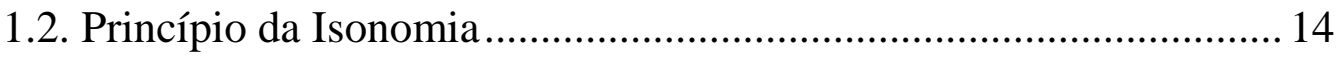

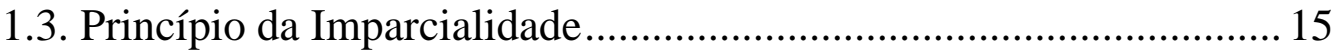

1.4. Princípio da Confidencialidade ………………………..................... 18

1.5. Princípio da Independência .............................................................. 21

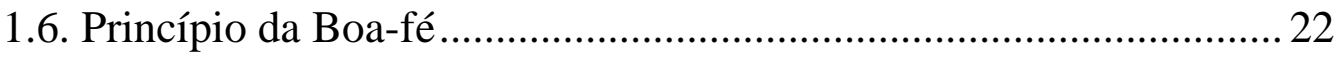

1.7. Princípio da Busca do Consenso ………………………………..... 23

CAPÍTULO 2 - Conceito, Importância e Aplicabilidade da Cláusula Compromissória de Mediação............................................................................. 26

CAPÍTUlO 3 - Requisitos da Cláusula Compromissória de Mediação

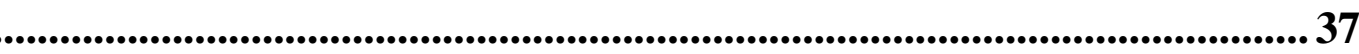

3.1. Prazo mínimo e máximo para a realização da primeira reunião de

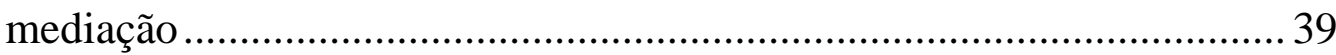

3.2. Local da primeira reunião de mediação............................................. 41

3.3. Critérios de escolha do(s) mediador(es) ………………………....... 42

3.4. Penalidade em caso de não comparecimento à primeira reunião de

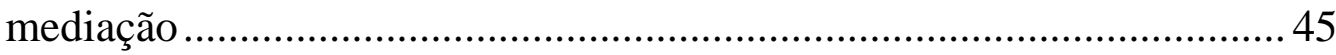

CAPÍtulO 4 - Efeito Suspensivo da Cláusula Compromissória de Mediação. 52

CAPÍTUlO 5 - Questão Controversa da Inclusão de Cláusula Compromissória de Mediação em Contratos de Adesão ........................... 56

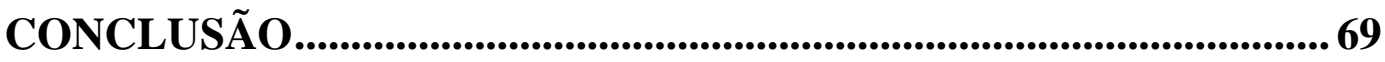

REFERÊNCIAS BIBLIOGRÁFICAS .................................................... 72 


\section{LISTA DE ABREVIAÇÕES}

CF - Constituição Federal de 1988

Lei de Mediação - Lei no 13.140 de 2015

CC/02 - Código Civil de 2002

CPC - Código de Processo Civil de 2015

CDC - Código de Defesa do Consumidor

REsp - Recurso Especial

STJ - Superior Tribunal de Justiça 


\section{INTRODUÇÃO}

Recentemente, com a edição da Lei 13.140 de 2015 (Lei de Mediação) e do novo CPC reconheceu-se em definitivo o movimento de mudança de paradigma da lógica adversarial - antes absoluta - para a lógica consensual de solução de conflitos, não somente na esfera extrajudicial, como em âmbito judicial.

Nesse contexto, as novas previsões legislativas estimulam a cultura pautada no diálogo e cooperação e traduzem o anseio da sociedade civil por soluções mais vantajosas e interessantes para conflitos nos quais uma decisão imposta por um terceiro se mostra inadequada, destacando-se o instituto da Mediação como um instrumento de autocomposição relevantíssimo nesse cenário, que contribui com restabelecimento da comunicação entre as partes, celeridade, diminuição de custos, dentre outras coisas.

Na mediação, as partes são auxiliadas por um terceiro imparcial que facilita a sua comunicação e permite que as mesmas assumam a autoria na resolução de suas controvérsias construindo "em conjunto, um sistema de decisão, satisfazendo a todos os envolvidos e oxigenando as relações sociais"1.

Acerca da Mediação, Tânia Almeida² elucida que esta deve ser pensada "como alternativa ao litígio, e não ao Judiciário, e considerar as repercussões de sua prática sobre o descongestionamento dos tribunais como consequência, e não como objetivo". Dessa forma, considerando a sua capacidade restaurativa, a mediação mostra-se ferramenta adequada e

\footnotetext{
${ }^{1}$ HALE, Durval et al.. O marco legal da mediação no Brasil. São Paulo: Editora Atlas, 2015 In: CHASE, Oscar, G. I metodi alternativi di soluzione dele controversie e la cultura del processo: il caso degli Stati Uniti D'America. In: VARANO, Vincenzo (Org.). L'altragiustizia: il metodi alternativi di soluzione dele controversie nel diritto comparato. Milano: Giuffrè, 2007. p. 129-156. ${ }^{2}$ ALMEIDA, Tânia. Mediação de Conflitos: Um meio de prevenção e resolução de controvérsias em sintonia com a atualidade. Mediare. Disponível em: $<$ http://www.mediare.com.br/2016/03/01/mediacao-de-conflitos-um-meio-de-prevencao-eresolucao-de-controversias-em-sintonia-com-a-atualidade/>. Acesso em: 21 abr. 2016.
} 
muito útil para a preservação de relações futuras, dentre elas as relações contratuais, nas quais é interessante a manutenção de vínculos profícuos para uma potencial relação negocial futura.

Conforme se verá, a inclusão de cláusulas contratuais prevendo a eleição da mediação como fase inicial no tratamento de contendas vem crescendo paulatinamente, o que revela que a busca de saídas consensuais como fase precedente à instauração de litígio tem sido reputada uma opção interessante ao trato contencioso ${ }^{3}$.

Fernanda Tartuce ensina que:

Na celebração de negócios jurídicos, o consenso pode se perder por inúmeros fatores humanos. A mediação na seara contratual é vantajosa porque ela não só viabiliza o tratamento de aspectos objetivos de um contrato, como também pode levar em conta determinados fatores subjetivos da inter-relação existente para superar as dificuldades ${ }^{4}$.

Atento à essa tendência, o legislador finalmente inovou na Lei de Mediação trazendo em seu bojo uma série de dispositivos que consagram a possibilidade de inclusão de Cláusula Compromissória de Mediação em contrato $^{5}$. Essa nova alternativa positivada na Lei viabiliza que partes se

\footnotetext{
3 TARTUCE, Fernanda. Mediação nos conflitos civis. $3^{\text {a }}$ ed. ver. atual e ampl. Rio de Janeiro: Forense. São Paulo: Método, 2016. p. 321.

${ }^{4}$ Ibid., p. 323.

${ }^{5}$ Art. $2^{\circ}$ A mediação será orientada pelos seguintes princípios (...)

$\S 1$ 으 $\mathrm{Na}$ hipótese de existir previsão contratual de cláusula de mediação, as partes deverão comparecer à primeira reunião de mediação.

Art. 22. A previsão contratual de mediação deverá conter, no mínimo: (...)

$\S 1^{\circ}$ A previsão contratual pode substituir a especificação dos itens acima enumerados pela indicação de regulamento, publicado por instituição idônea prestadora de serviços de mediação, no qual constem critérios claros para a escolha do mediador e realização da primeira reunião de mediação.

$\S 2^{\circ}$ Não havendo previsão contratual completa, deverão ser observados os seguintes critérios para a realização da primeira reunião de mediação: (...)

$\S 3^{\circ}$ Nos litígios decorrentes de contratos comerciais ou societários que não contenham cláusula de mediação, o mediador extrajudicial somente cobrará por seus serviços caso as partes decidam assinar o termo inicial de mediação e permanecer, voluntariamente, no procedimento de mediação. Art. 23. Se, em previsão contratual de cláusula de mediação, as partes se comprometerem a não iniciar procedimento arbitral ou processo judicial durante certo prazo ou até o implemento de determinada condição, o árbitro ou o juiz suspenderá o curso da arbitragem ou da ação pelo prazo previamente acordado ou até o implemento dessa condição.

Parágrafo único. $\mathrm{O}$ disposto no caput não se aplica às medidas de urgência em que o acesso ao Poder Judiciário seja necessário para evitar o perecimento de direito.
} 
comprometam a intentarem resolver controvérsias futuras advindas do contrato de forma consensual.

Importante notar, que uma vez surgido o conflito torna-se muito mais difícil as partes chegarem em um consenso com relação a forma de solução dessa controvérsia, daí a importância dessa novidade na Lei.

Dito isso, o presente trabalho propõe-se a analisar minuciosamente todos os aspectos que abrangem a previsão contratual de cláusula compromissória de mediação, tendo em vista o seu papel de uma das molas propulsoras de tentativa de solução consensual por meio da mediação.

Mais do que isso, o estudo pretende conscientizar o leitor acerca da importância e implicações trazidas com a positivação da cláusula compromissória de mediação. 


\section{CAPÍTULO 1 - BASE PRINCIPIOLÓGICA DA CLÁUSULA COMPROMISSÓRIA DE MEDIAÇÃO}

A força normativa dos princípios jurídicos assume hoje papel central no processo de aplicação da lei. A mesma premissa estende-se a particulares que elegem a mediação como meio apto a sanar uma desavença contratual. Nesse sentido, entende-se que a cláusula compromissória de mediação é norteada pela observância de uma série de princípios a fim de concretizar suas finalidades e atingir as expectativas dos participantes que elegeram a mediação como método autocompositivo para a solução de seus conflitos contratuais.

Hale, Pinho e Cabral elucidam que, no caso da mediação, a existência de regras próprias e escopos específicos, bastante peculiares em relação ao processo judicial - método tradicional de resolução de conflitos monopolizado pelo Estado - reforçam a necessidade de previsão legal dos seus princípios fundamentais para conferir sistematicidade e coerência ao instituto $^{6}$, cânones estes que guiam a atuação do mediador, dos mediandos e a natureza do procedimento.

Na hipótese de colisão entre os princípios da mediação, o conflito poderia ser sanado através da ponderação, eis que é impossível falar em hierarquia no que toca a princípios. Nesse contexto, os participantes teriam a faculdade de abrandar o princípio da confidencialidade em nome do princípio da autonomia da vontade por exemplo.

Importante destacar que o primeiro projeto de lei sobre mediação no Brasil (PL 4.827 de 1998) não apontou os princípios que embasam o instituto, princípios estes que foram positivados apenas com o advento do novo Código de Processo Civil que disciplinou a mediação incidental ao processo judicial e se encarregou de enumerar os princípios norteadores da

\footnotetext{
${ }^{6}$ HALE, Durval et al.. O Marco Legal da Mediação no Brasil: Comentários à Lei no 13.140, de 26 de junho de 2015. $1^{\text {a }}$ ed. São Paulo: Atlas, 2016. p. 51.
} 
mediação. Em que pese hajam pequenas diferenças, a estrutura de diretrizes e princípios consignados posteriormente na nova Lei de mediação é similar.

O novo Código de Processo Civil reconhece no seu art. 166 serem princípios da mediação a (i) independência; (ii) imparcialidade; (iii) autonomia da vontade; (iv) confidencialidade; (v) oralidade; (vi) informalidade, e (vi) decisão informada.

Em consonância com o novo código, a Lei nº 13.140/2015 evidencia no art. $2^{\circ}$, que o instituto da mediação será norteado pelos seguintes princípios: (i) imparcialidade; (ii) isonomia; (iii) oralidade; (iv) informalidade; (v) autonomia da vontade das partes; (vi) busca do consenso; (vii) confidencialidade; e (viii) boa-fé.

Vale evocar também a Resolução $n^{\circ} 125 / 2010$, do CNJ que trata da Política Judiciária Nacional de tratamento adequado dos conflitos de interesses, que traz contribuição significativa em seu Código de Ética de Conciliadores e Mediadores Judiciais ao listar uma série de princípios que regem a atividade dos mediadores, guardando coerência com os da nova lei de mediação.

Conquanto não esteja expresso em lei, é primordial que o mediador, ao iniciar a primeira sessão de mediação informe aos participantes acerca dos princípios que orientam o procedimento, conforme estabelece o art. $2^{\circ}$ do Código de Conduta para Mediadores, anexo à Resolução n n 125/2010 do CNJ, para que estejam aptos a levantar a existência de eventual descumprimento a algum dos cânones.

O que se propõe em seguida é esmiuçar a gama de princípios indispensáveis ao exercício da cláusula compromissória de mediação. 


\subsection{Princípio da Autonomia da Vontade/Protagonismo/Autoria}

A autonomia da vontade dos participantes na mediação, insculpida no art. $2^{\circ}, \mathrm{V}$ da Lei $\mathrm{n}^{\circ} 13.140$, deve ser compreendida da forma mais abrangente possível. Conforme lecionam Hale, Pinho e $\mathrm{Cabral}^{7}$, no âmbito da mediação, a autonomia da vontade deve abarcar: (i) a aceitação livre e voluntária da mediação (e a possibilidade de interrompê-la a qualquer momento); (ii) a indicação do mediador (ou a possibilidade de oposição àquele eleito por distribuição, em caso de mediação judicial); (iii) a participação direta e espontânea no procedimento; e, (iv) a autodeterminação para, ao final, celebrar ou não um acordo.

Nessa esteira, a vontade das partes é soberana no instituto da mediação. Nas palavras de Fernanda Tartuce ${ }^{8}$ :

(...) a mediação permite que o indivíduo decida os rumos da controvérsia e protagonize uma saída consensual para o conflito: ao incluir o sujeito como importante ator na abordagem da crise, valoriza-se sua percepção e considera-se seu senso de justiça. Como facilmente se percebe, a autonomia da vontade está ligada à dignidade e à liberdade.

Importante notar, conforme destacam Alexandre Assed e Larissa Davidovich, que a inclusão da cláusula compromissória de mediação em um contrato firmado entre as partes foi feita de maneira respeitosa ao princípio da autonomia da vontade, em consonância com os $\S^{\circ}$ e $2^{\circ}$ do artigo $2^{\circ}$ da Lei que dispõe que em caso de previsão contratual de Mediação as partes são obrigadas a comparecer à primeira reunião, não sendo, contudo, obrigadas a permanecer em procedimento de Mediação 9 .

Vê-se portanto, que embora a adoção da cláusula de mediação em um contrato importe no compromisso de atender à primeira sessão, as partes ao acolherem essa condição não abdicam do poder de decidirem

\footnotetext{
${ }^{7}$ HALE, Durval et al.. O marco legal da mediação no Brasil. São Paulo: Editora Atlas, 2015. p. 61.

${ }^{8}$ TARTUCE, 2016, p. 190.

${ }^{9}$ ASSED, Alexandre Servino \& DAVIDOVICH, Larissa. A Nova Lei de Mediação: Comentários e Reflexões. In: PELAJO, Samantha et al.. (Coord.). Mediação de Conflitos para Iniciantes, Praticantes e Docentes. Parte I. Cap. 21. Salvador: Ed. JusPodvim, 2016. p. 345.
} 
livremente qual será o rumo da discussão. Nesse contexto, podemos imaginar um cenário em que as partes entendam que a arbitragem, ou até mesmo a via judicial seja a mais adequada para a solução da questão, ou ao contrário, que os mediandos se identifiquem com a proposta do instituto e decidam adotá-lo até o fim.

Inobstante eleita a mediação conforme a cláusula compromissória, nada impede que as partes após a realização de inúmeras reuniões conjuntas e privadas optem por abandonar o procedimento. Observa-se assim, que a cláusula compromissória é ferramenta aliada ao princípio da autonomia da vontade, e não busca balizá-lo, mas sim, instigar as partes a conhecerem melhor o instituto da mediação, deixando-as à vontade para decidir qual o melhor caminho a seguir.

Ademais, a Lei de Mediação privilegia a vontade das partes ao conferir-lhes o poder de estabelecerem critérios para a realização da mediação, respeitando alguns requisitos mínimos previstos no art. $22^{10}$ que serão pormenorizados em capítulo posterior.

A estima ao princípio da autonomia da vontade é tão predominante, que o legislador previu no art. 23 da Lei $^{11}$ que caso as partes firmem contrato com cláusula de mediação elas poderão comprometer-se a não litigarem no campo da arbitragem ou judiciário durante determinado prazo ou até o implemento de uma condição, - ressalvada a necessidade de medida de urgência - e caso esta disposição seja burlada, o juiz ou árbitro

\footnotetext{
${ }^{10}$ Art. 22. A previsão contratual de mediação deverá conter, no mínimo:

I - prazo mínimo e máximo para a realização da primeira reunião de mediação, contado a partir da data de recebimento do convite;

II - local da primeira reunião de mediação;

III - critérios de escolha do mediador ou equipe de mediação;

IV - penalidade em caso de não comparecimento da parte convidada à primeira reunião de mediação.

${ }^{11}$ Art. 23. Se, em previsão contratual de cláusula de mediação, as partes se comprometerem a não iniciar procedimento arbitral ou processo judicial durante certo prazo ou até o implemento de determinada condição, o árbitro ou o juiz suspenderá o curso da arbitragem ou da ação pelo prazo previamente acordado ou até o implemento dessa condição.

Parágrafo único. $\mathrm{O}$ disposto no caput não se aplica às medidas de urgência em que o acesso ao Poder Judiciário seja necessário para evitar o perecimento de direito.
} 
suspenderá o processo até que o prazo seja escoado ou a condição concretizada.

O princípio da autonomia da vontade na mediação anda de mãos dadas aos princípios do protagonismo e da autoria, visto que a mediação demanda que os participantes sejam protagonistas de suas ações e discursos. Conforme esclarece Tânia Almeida:

A mediação foi pensada de modo a devolver às partes o protagonismo sobre suas vidas no que concerne à solução de suas contendas. Distancia-se do modelo paternalista (...) e procura restaurar a capacidade de autoria das partes na solução de seus conflitos ${ }^{12}$.

Resta evidente que os mediandos se tornam responsáveis pela solução da controvérsia como agentes ativos e porta vozes de seus sentimentos. Diogo Almeida e Fernanda Paiva ${ }^{13}$ ensinam que:

A autoria está presente na identificação de alternativas e, posteriormente na escolha de soluções, contrapondo-se à concepção de decisão proferida por adjudicação.

Seguindo essa linha de raciocínio, o mediador deve atuar como um facilitador do diálogo, visto que apenas as partes têm poder decisório no conflito, em respeito ao princípio da autonomia da vontade.

Lilia Maia de Morais Sales, ao analisar o tema conclui que:

(...) as partes é que decidirão todos os aspectos do problema sem intervenção do mediador, no sentido de induzir as respostas ou decisões, mantendo a autonomia e controle das decisões relacionadas ao conflito. O mediador facilita a comunicação, estimula o diálogo, auxilia na resolução dos conflitos, mas não os decide $^{14}$.

\footnotetext{
${ }^{12}$ ALMEIDA, Tania. Mediação e Conciliação: Dois paradigmas distintos, duas práticas diversas. In: CASTELLA, Paulo Borba \& SOUZA, Luciane Moessa de (Coords.). Mediação de Conflitos Novo Paradigma de Acesso à Justiça. Belo Horizone: Ed. Fórum, 2009. p. 96.

${ }^{13}$ ALMEIDA, Diogo A. Rezende de \& PAIVA, Fernanda. Princípios da Mediação de Conflitos. In: PELAJO, Samantha et al.. (Coord.). Mediação de Conflitos para Iniciantes, Praticantes e Docentes. Parte I. Cap. 5. Salvador: Ed. JusPodvim, 2016. p. 104.

${ }^{14}$ SALES, Lilia Maia de Morais. Justiça e mediação de conflitos. Belo Horizonte: Del Rey, 2003. p. 47.
} 


\subsection{Princípio da Isonomia}

O princípio da isonomia, garantia fundamental prevista no art. $5^{\circ}$, caput e inciso I, e art. $7^{\circ}$, incisos XXX e XXXI da Constituição Federal, implica não somente a igualdade das partes perante a lei, conhecida como "igualdade formal", mas também o impedimento de distinções fundadas nas peculiaridades dos indivíduos, o que se entende por "igualdade material".

Isso é dizer que o princípio da isonomia no âmbito da mediação, previsto no inciso II, art. $2^{\circ}$ da Lei $n^{\circ} 13.140$, baliza a atuação do mediador, para que este não empregue tratamento específico, vantajoso ou prejudicial aos mediandos. Dessa forma, cada participante da mediação recebe as mesmas oportunidades de escuta e manifestação inexistindo qualquer condição de desigualdade, independente de disparidade econômica, de poder, formulação de ideias, etc.

Nesse contexto, ao optarem pela inclusão da cláusula de mediação na relação contratual as partes consentem que na hipótese de eventual litígio, a realização da mediação deverá respeitar uma série de requisitos previstos no art. 22 da Lei, e estes pressupostos serão a princípio decididos igualmente entre as partes à época da celebração do contrato.

Dito de outra forma, é irrelevante o poderio econômico de uma parte ou a vulnerabilidade de outra pois os pontos como o prazo a ser fixado para o início da mediação, ou a penalidade a ser aplicada em caso de ausência na primeira reunião serão inseridos na cláusula compromissória dadas chances iguais de manifestação das partes.

Segundo Hale, Pinho e Cabral:

$\mathrm{O}$ princípio autoriza, ainda, que o mediador, em respeito às particularidades distintas de cada indivíduo, atue para dar aos mediandos iguais espaço e voz, através do manejo adequado das técnicas e das ferramentas de mediação - desde 
que dentro dos limites de suas funções e mantida a sua necessária imparcialidade ${ }^{15}$.

Imaginemos a hipótese em que há parte hipossuficiente na relação. Nesse caso, se o mediador constatar que esta parte não tem conhecimento de seus direitos essenciais compete-lhe sugerir à parte que busque a assessoria de um advogado.

Atento a esse princípio, o legislador buscou socorrer a parte em situação de disparidade no art. 10, parágrafo único da Lei $n^{\circ} 13.140$, ao prever a suspensão da mediação judicial, caso haja uma parte assistida por advogado e outra sem assistência.

Em síntese, em cenário de desigualdade entre os participantes da mediação, o mediador deve zelar pelas necessidades e dificuldades dos sujeitos. Conforme exposto na obra de Fernanda Tartuce:

(...) se, por exemplo, um deles não é alfabetizado, o mediador deve intervir para estabelecer igualdade de condições. Uma iniciativa possível seria perguntar se alguém poderia acompanha-lo nas reuniões destinadas a tratar de contratos e questões formais; a pergunta também deve ser feita à outra parte.... é bom externar preocupação com a igualdade em relação a ambas as partes, embora seja muito provável que a mais esclarecida dispense tal auxílio por acha-lo desnecessário ${ }^{16}$.

\subsection{Princípio da Imparcialidade}

Ponto em comum tanto dos meios alternativos de resolução de conflito, como dos meios jurisdicionais é a presença de um terceiro imparcial. A imparcialidade à luz da Resolução no 125/2010 do CNJ se traduz no dever de o mediador - seja ele eleito pelas partes ou pela instituição de mediação - "agir com ausência de favoritismo, preferência ou

\footnotetext{
${ }^{15}$ HALE, 2016, p. 59.

${ }^{16}$ AZEVEDO, André Gomma (org.) Manual de mediação judicial. $4^{\mathrm{a}}$ ed. Brasília/DF: Ministério da Justiça e Programa das Nações Unidas para o Desenvolvimento - PNUD, 2013. p. 172. Disponível em: <http://www.cnj.jus.br/images/programas/conciliacao/manual_mediacao_judicial_4ed.pdf>. Acesso em: 17 set. 2016.
} 
preconceito", de modo que seus valores não interfiram no deslinde da lide em questão.

Nessa linha, Hale, Pinho e Cabral definem-na como a equidistância de ausência de comprometimento do mediador em relação aos envolvidos no conflito ${ }^{17}$.

Impende ressaltar que a exigência de uma postura imparcial de maneira nenhuma impõe a abstenção total do uso da razão e da emoção, sentimentos inerentes à condição humana. $\mathrm{O}$ que se espera ao inserir uma cláusula de mediação em um contrato é que por força do princípio da imparcialidade, o mediador não tome partido e seja capaz de impedir que qualquer juízo interno de valor afete a execução de seu labor. Nas palavras de Hale, Pinho e Cabral na obra "O Marco Legal da Mediação no Brasil: Comentários à Lei no 13.140de 26 de junho de 2015", é impossível exigir que o mediador funcione de forma neutra, totalmente despido de convicções próprias e ideologias.

Assim, o mediador deve conduzir o procedimento oportunizando as mesmas chances de manifestação às partes, e administrando a controvérsia de maneira que os participantes possam expressar-se de forma isonômica, conforme o art. $2^{\circ}$, inciso I da Lei de Mediação.

Ademais, o terceiro imparcial deve ser completamente alheio aos interesses das partes, fazendo-se mister que qualquer vínculo anterior do mediador com os mediandos deva ser revelado de antemão.

Cumpre destacar que a nova Lei de mediação perfilha como vícios que maculam o princípio da imparcialidade do mediador as mesmas hipóteses de impedimento e suspeição constantes do processo judicial em seu artigo $5^{\circ 18}$, o que também foi reproduzido no novo Código de Processo Civil, e na Resolução $n^{\circ} 125 / C N J$, podendo sob a égide da legislação, o

\footnotetext{
${ }^{17}$ HALE, 2016, p. 204.

${ }^{18}$ Art. 134 do NCPC.
} 
participante da mediação optar por recusar o mediador diante de qualquer dúvida acerca da sua imparcialidade (art. $5^{\circ}$, parágrafo único).

A título de exemplo, caso o mediador tenha atuado como consultor ou advogado de uma das partes, em matéria alheia à mediação. Nesse caso, pode o mediando manifestar a vontade de afastar a atuação do mediador por acreditar que este fato compromete a parcialidade do mediador.

Quanto à indagação de que o princípio da imparcialidade poderia ou não ser relativizado em face da autonomia da vontade, a resposta variará de acordo com o tipo de mediação que está em jogo.

Como se sabe, no processo judicial, os casos legais de impedimento do juiz provocam nulidade processual absoluta e insanável, enquanto os de suspeição implicam em nulidade relativa, sendo passíveis de convalidação. Em se tratando de mediação judicial, Hale, Pinho e Cabral ${ }^{19}$ entendem que:

O mesmo tratamento (dado ao processo judicial) deva ser estendido às hipóteses de impedimento e suspeição do mediador, por este ser um auxiliar do juízo.

Ao contrário, na esfera da mediação extrajudicial é possível acolher o entendimento de que o princípio da imparcialidade poderia ceder frente à autonomia da vontade, pois aqui o dever do mediador se limita apenas em informar as partes acerca de eventual impedimento, e caso estas não se sintam afetadas com o que foi exposto têm a faculdade de dar seguimento à mediação.

Pontue-se que, caso as partes entendam que a melhor alternativa é o afastamento do mediador, estas poderão escolher outro mediador em qualquer fase do procedimento. Em outro cenário, na hipótese de o próprio mediador não se sentir confortável em prosseguir com a mediação, compete-lhe declinar do encargo, primando pelos preceitos éticos do instituto.

\footnotetext{
${ }^{19}$ HALE, 2015, p. 57.
} 


\subsection{Princípio da Confidencialidade}

O princípio da confidencialidade no âmbito da mediação, elencado no inciso VII do art. $2^{\circ}$ da Lei $\mathrm{n}^{\circ} 13.140$, rege tanto o procedimento do instituto em si, como a atuação do mediador, das partes, de seus prepostos, advogados assessores técnicos e qualquer pessoa presente nas sessões de mediação ${ }^{20}$. Diferentemente do processo judicial, que salvo casos excepcionais envolvendo temas de direito de família é de natureza pública, o procedimento da mediação em regra é sigiloso, fator que faz a mediação despontar com meio vantajoso de resolução de conflito para muitas pessoas que desejam preservar a sua privacidade.

A confidencialidade é mantida quando falamos da cláusula compromissória. Isso significa que ao inserirem a referida ressalva no contrato, as partes não precisam externalizar para terceiros que não estejam envolvidos na relação contratual, que a cláusula foi redigida, da mesma maneira que seus advogados devem guardar sigilo.

A esse respeito, André Gomma Azevedo ${ }^{21}$ lembra que:

As informações constantes nas comunicações realizadas na mediação não poderão ser ventiladas fora desse processo nem poderão ser apresentadas como provas no eventual julgamento do caso, nem em outros processos judiciais.

Conforme art. 30 da Lei $\mathrm{n}^{\circ} 13.140$.

Contudo, essa confidencialidade não é absoluta, eis que a segunda parte do dispositivo supramencionado, permite que as partes expressamente decidam de forma diversa. Além disso, quando a divulgação da informação for exigida por lei ou necessária para cumprimento de acordo obtido pela mediação, a confidencialidade também será excepcionada.

Conforme o ensinamento de Humberto Pinho:

${ }^{20}$ Art. 30, parágrafo primeiro da Lei 13.140 de 2015.

${ }^{21}$ AZEVEDO, 2013, p. 233. 
A confidencialidade é um instrumento apto a conferir um elevado grau de compartilhamento para que as pessoas se sintam à vontade para revelar informações íntimas, sensíveis e muitas vezes estratégicas que certamente não exteriorizariam em um procedimento pautado pela publicidade ${ }^{22}$.

Nessa esteira, qualquer pessoa que possua interesse em presenciar uma sessão de mediação, tanto privada quanto conjunta, deve ser expressamente autorizada pelos mediandos, consoante o art. 31 da nova Lei de Mediação.

Cumpre destacar que a nova Lei de mediação destacou em seu art. 14 que é dever do mediador esclarecer às partes de antemão na primeira sessão de mediação acerca do princípio da confidencialidade, que abrange desde documentos até o discurso das partes.

Mais além, a confidencialidade foi exemplificada em rol não taxativo como (i) declaração, opinião, sugestão, promessa ou proposta formulada por uma parte à outra na busca de entendimento para o conflito; (ii) reconhecimento de fato por qualquer das partes no curso do procedimento de mediação; (iii) manifestação de aceitação de proposta de acordo apresentada pelo mediador; (iv) documento preparado unicamente para os fins do procedimento de mediação ${ }^{23}$.

No que tange os participantes da mediação, o papel do mediador é auxiliá-los a negociarem a extensão ou grau do sigilo a respeito das informações obtidas no curso do procedimento, e adverti-los quanto a importância da observância desse princípio. Suponhamos que uma parte viole o dever de confidencialidade que norteia a mediação, revelando em juízo o conteúdo de uma informação obtida no curso da mediação. Nesse caso, esta prova será ilícita em razão da transgressão ao referido princípio,

\footnotetext{
${ }^{22}$ PINHO, Humberto Dalla Bernardina de. (org.). A Nova Lei de Mediação Brasileira Comentários ao Projeto de Lei n ${ }^{\circ} 7169 / 14$. Revista Eletrônica de Direito Processual. Ano 8. Volume Especial. Rio de Janeiro, 2014. Disponível em: <https://www.academia.edu/8676991/Revista_Eletrônica_de_Direito_Processual_REDP_A_NO VA_LEI_DE_MEDIAÇÃO_BRASILEIRA_COMENTÁRIOS_AO_PROJETO_DE_LEI_N_7.16 914>. Acesso em: 03 mai. 2016.

${ }^{23}$ Art. 30, parágrafo primeiro da Lei n. 13.140.
} 
bem como o dever de lealdade e boa-fé, nos moldes do art. 30, § $2^{\circ}$ da Lei $n^{\circ} 13.140$.

Segundo Leonardo Carneiro da Cunha, a quebra da confiança e a apresentação de documento usado com a específica finalidade de tentar a autocomposição violam a boa-fé e a lealdade que integram o devido processo legal, devendo ser reconhecida a sua invalidade ante a configuração como prova ilícita ${ }^{24}$.

Em que pese a possibilidade de afastamento do princípio pelos participantes, a confidencialidade deve ser protegida no procedimento da mediação. Conforme adiantado acima, as sessões de mediação não são abertas ao público em geral, o que torna o instituto atraente para muitos e deixa os participantes mais confortáveis para externalizar seus sentimentos e interesses subjacentes.

Já na atuação do mediador, conforme esclarecem Diogo Almeida e Fernanda Paiva:

Diferentemente da sua influência na atividade das partes e na forma com a qual se desenvolve o procedimento, em relação ao mediador, a discrição é regra de eticidade. A violação da norma de sigilo pelo mediador pode sujeitá-lo à responsabilização na esfera civil, além das eventuais penalidades previstas no órgão ao qual está vinculado ${ }^{25}$.

Entende-se assim, que o mediador deve guardar sigilo do que the foi dito pelos mediandos em sessões privadas, e conjuntas, não podendo divulgar as informações obtidas através da mediação nem aos demais mediandos.

Ressalte-se que, o mediador sequer poderá ser indicado como testemunha em processo exterior ao da mediação conforme a Resolução

\footnotetext{
${ }^{24}$ CUNHA, Leonardo Carneiro da. Notas sobre ADR, confidencialidade em face do julgador $e$ prova inadmissível. Disponível em:

<http://www.leonardocarneirodacunha.com.br/opiniao/opiniao-26-notas-sobreadrconfidencialidade-em-face-do-julgador-eprova-enadmissivel/>. Acesso em: 15 set. 2016.

${ }^{25}$ ALMEIDA \& PAIVA, 2016, p. 109.
} 
125 de 2010, e na hipótese de este revelar qualquer informação oriunda de seu ofício responderá por crime tipificado no art. 154 do Código Penal.

Tema controvertido corresponde à possibilidade de um mediador abrandar o princípio da confidencialidade em prol de um bem maior. Isso é dizer, qual o entendimento deve prevalecer na hipótese de o mediador se deparar com informação que tem potencial de causar, ou mesmo, já causou a morte ou lesão física grave de um dos mediandos ou terceiros. Nesse caso, alguns teóricos possuem o entendimento de que o princípio da confidencialidade deve dar lugar ao bem maior, constituindo dever do mediador informar o referido fato à autoridade policial competente, em razão da prevalência dos direitos à vida e saúde em relação ao direito de privacidade.

Cumpre destacar por fim, que no novo Código de Processo Civil o princípio da confidencialidade foi alçado como um dos aspectos mais valorizados na mediação judicial, eis que a violação por parte dos mediadores judiciais a este princípio lhes acarreta a exclusão do cadastro ${ }^{26}$.

\subsection{Princípio da Independência}

O princípio da independência, explica-se pela liberdade conferida ao mediador de conduzir o procedimento inexistindo qualquer pressão - seja interna ou externa - na sua atuação. Este cânone está elencado apenas no novo Código de Processo Civil ${ }^{27}$, não tendo sido trazido na nova Lei de mediação, mas correlacionando-se diretamente com o princípio da imparcialidade respaldado pelo novo diploma legal.

Contudo, faz-se mister lembrar que o mediador tem papel distinto de um juiz, portanto não impõe uma decisão aos mediandos, apenas orienta as partes para que não ocorra um desequilíbrio entre elas. Segundo Fabiana Spengler, em relação às partes, o mediador deve "mediá-las ou reconciliar

${ }^{26}$ BRASIL. Lei n. 13.105 de 2015, Art. 173.

27 Art. 166. 
os interesses conflitivos, conduzindo para que elas concluam com o seu impulso a melhor solução ${ }^{28}$.

Nesse sentido, as partes que preveem a mediação no contrato devem estar atentas para o fato de que caso o mediador conclua que o conflito é impassível de resolução por meio da mediação, por qualquer motivo plausível ou não, este pode interromper, recusar ou suspender a sessão de mediação.

Apenas a título de ilustração, caso o mediador venha a entender que determinado acordo alcançado pelas partes mostra-se inexequível ou ilegal, ele poderia abster-se de redigi-lo, nos moldes do art. $1^{\circ}, \mathrm{V}$ do Código de Ética para Mediadores e Conciliadores, anexo à Resolução 125 de 2010 do CNJ, independente do pedido das partes.

\subsection{Princípio da Boa-fé}

O princípio da boa-fé aplicado à mediação, consiste na atuação de todos os seus participantes com lealdade, honestidade, e probidade, fatores imprescindíveis para a aquisição da confiança no decorrer do procedimento. Dito de outra forma, este cânone, previsto no art. $2^{\circ}$, inciso VIII da Lei ${ }^{\circ}$ 13.140, intrinsecamente ligado à confidencialidade, impõe cooperação entre os mediandos e mediador, o modo colaborativo no tratamento, o respeito, consideração e cuidado recíprocos.

Quanto à boa-fé no contexto da cláusula compromissória de mediação, esta é imprescindível. Veja-se, que caso as partes redijam esta cláusula no contrato, as mesmas estarão obrigadas a comparecer à primeira reunião de mediação ${ }^{29}$, constituindo um compromisso integralmente pautado pelo princípio da boa-fé objetiva. Dessa forma, como explana

\footnotetext{
${ }^{28}$ SPENGLER, Fabiana Marion. Da Jurisdição à mediação: por uma outra cultura no tratamento de conflitos. Ijuí: Unijuí, 2010. p. 321.

${ }^{29}$ Art. $2^{\circ}$ A mediação será orientada pelos seguintes princípios: (...)

$\S 1^{\circ} \mathrm{Na}$ hipótese de existir previsão contratual de cláusula de mediação, as partes deverão comparecer à primeira reunião de mediação.
} 
Fernanda Tartuce ${ }^{30}$, a Lei de Mediação evidencia um encorajamento da boa-fé.

Assim, queda claro que a mediação somente se dará de forma harmoniosa, se presente o "sentimento e convencimento íntimos quanto à lealdade, honestidade e à justiça do próprio comportamento em vista da realização dos fins para os quais este é direcionado"31.

\subsection{Princípio da Busca do Consenso}

Conquanto a mediação não esteja necessariamente focada na busca pelo acordo, mas sim no restabelecimento do diálogo e da comunicação entre as partes, importante mencionar o princípio da busca do consenso, inerente à autocomposição. O referido princípio não está no rol dos princípios que constam no novo CPC, contudo, foi destacado no art. $2^{\circ}$, VI da nova Lei de Mediação.

O que se pretende com a previsão legislativa da cláusula compromissória de mediação no novo marco legal é justamente estimular a busca pelo consenso, conscientizando a sociedade civil acerca da mediação e de seus benefícios, de forma a propagar o instituto e evitar que muitos conflitos facilmente mediáveis entrem na fila de espera do já assoberbado judiciário.

Assim, importante se ter em mente que esse método de resolução consensual de conflito não vem para substituir o judiciário, mas sim para conversar harmoniosamente com ele. Isso porque há uma série de conflitos que merecem a atenção do judiciário, tais como conflitos complexos que dependem de perícia, desavenças passadas fruto de relações isoladas e controvérsias nas quais o restabelecimento da comunicação não é o foco central.

\footnotetext{
${ }^{30}$ TARTUCE, Op. cit., p. 321.

31 ABDO, Helena Najjar. Abuso do processo. São Paulo: RT, 2007. In: TARTUCE, Fernanda. Mediação nos conflitos civis. $3^{\mathrm{a}}$ ed. ver. atual e ampl. Rio de Janeiro: Forense. São Paulo: Método, 2016. p. 210.
} 
Acerca do tema, Mauro Cappelletti ${ }^{32}$ leciona que:

A decisão judiciária proferida em sede contenciosa (estritamente jurisdicional) se presta, otimamente, para resolver relações isoladas e meramente inter-individuais. É que a decisão tomada em sede contenciosa está ordinariamente destinada a atingir um fenômeno do passado, que não está fadado a perdurar.

Muito embora o legislador tenha positivado o princípio da busca do consenso, confirmando-o como pilar do instituto da mediação, há controvérsias acerca da sua aplicação. Conforme o pensamento de muitos doutrinadores, este princípio não seria essencial à mediação, pois engloba todo o procedimento autocompositivo, e que o desfecho positivo da mediação não está necessariamente atrelado ao acordo, considerando que "a mediação não pode e não deve ser medida unicamente pelo êxito constante do Termo de Entendimento"33.

Nessa mesma linha, no âmbito da mediação judicial o novo CPC dispõe em seu art. 167 , p. $3^{\circ}$ que:

Do credenciamento das câmaras e do cadastro de conciliadores e mediadores constaram todos os dados relevantes para a sua atuação, tais como o número de processos que participou, o sucesso ou insucesso da atividade, a matéria sobre a qual versou a controvérsia, bem como outros dados que o tribunal julgar relevantes.

Previsão que acaba por impulsionar o viés meramente quantitativo do princípio da busca do consenso.

Desse modo, caso entendamos que o resultado positivo da mediação não está associado à celebração de um acordo, resta cristalino que:

\footnotetext{
${ }^{32}$ CAPPELLETTI, Mauro. Libertà Individuale e Giustizia Sociale nel Processo Civile. Giustizia e Società. Milano: Edizioni di Comunità, 1977. p. 32 apud CUNHA, J. S. Fagundes. Da mediação e da arbitragem endoprocessual. In: Revista dos Juizados Especiais. v. 4. n. 14. São Paulo: Editora Fiuza, out./dez. 1999. Disponível em: <http://www.uepg.br/rj/a1v1at16.htm>. Acesso em: 23 mar. 2016.

MITIDIERO, Daniel. Colaboração no Processo Civil - Pressupostos Sociais, Lógicos e Éticos, $2^{\mathrm{a}}$ ed. São Paulo: Revista dos Tribunais, 2011. p. 33-34.

${ }^{33}$ ALBERTON, Genaceia da Silva. O Núcleo de Estudos no contexto da mediação no Rio Grande do Sul e as proposições legislativas na área da mediação. Disponível em: $<$ http://www.ajuris.org.br/sitenovo/wp-content/uploads/2014/12/o-nucleo-de-estudos-no-contextoda-mediacao.pdf $>$. Acesso em: 18 set. 2016.
} 
(...) a definição de qualidade em mediação consiste no conjunto de características necessárias para o processo autocompositivo que irá, dentro de condições éticas, atender e possivelmente até exceder as expectativas e necessidade do usuário. Pode-se, portanto, considerar "bem-sucedida" a mediação quando o "sucesso" está diretamente relacionado à satisfação da parte ${ }^{34}$.

Assim, embora a formulação de um acordo seja incentivada, não se pode olvidar que este não é o único fim da mediação, e que o procedimento pode ser frutífero, independentemente da formação de consenso.

Caso não culmine em acordo, a mediação será bem-sucedida se tiver facilitado o diálogo entre as partes e estimulado sua capacidade de entenderem-se sozinhas. Nesse cenário, o mediador deve ter direito ao pagamento de seus honorários mesmo quando não há acordo entre as partes mediadas no fim reunião, até porque o acordo pode advir após a mediação, como consequência do instituto.

${ }^{34}$ AZEVEDO, 2013, p. 106. 


\section{CAPÍTULO 2 - CONCEITO, IMPORTÂNCIA E APLICABILIDADE DA CLÁUSULA COMPROMISSÓRIA DE MEDIAÇÃO}

Uma das inovações relevantes trazidas no bojo da Lei $\mathrm{n}^{\circ} 13.140$ de 2015 consiste na opção do legislador em prever a chamada cláusula compromissória de mediação. A referida cláusula, alicerçada na autonomia da vontade das partes e demais princípios descritos no capítulo anterior, dá aos mediandos à ocasião da celebração de um contrato a opção de elegerem a mediação como meio de solução de eventual controvérsia oriunda da relação obrigacional, estimulando a eleição desse método autocompositivo.

Ao instituírem a cláusula compromissória de mediação no contrato, as partes o fazem com o fim de preservar um bom relacionamento comercial, bem como para diminuir os custos de transação desse contrato.

Uma vez surgido o conflito, torna-se muito mais difícil as partes chegarem em um consenso com relação a forma de solução desse conflito, daí a importância da inserção da cláusula de mediação no contrato. Assim, caso aflore uma desavença, as partes terão uma preocupação a menos.

Conforme adiantado acima, se infere pela leitura do art. $2^{\circ}$, $\S 1^{\circ}$ da Lei de Mediação que, caso haja previsão contratual de cláusula de mediação, impõe-se às partes a obrigatoriedade de comparecimento à primeira reunião de mediação ${ }^{35}$. Importante notar, que o artigo não tem o efeito de compelir as partes a seguirem com a mediação até o fim, eis que o $\S 2^{\circ}$ esclarece que nenhuma parte será obrigada a permanecer em procedimento de mediação.

Cumpre salientar que o legislador foi alvo de críticas ao impor a obrigatoriedade de comparecimento à primeira reunião de mediação, pois

\footnotetext{
${ }^{35}$ Art. $2^{\circ} \S 1^{\text {a }} \mathrm{Na}$ hipótese de existir previsão contratual de cláusula de mediação, as partes deverão comparecer à primeira reunião de mediação.
} 
não foi feita nenhuma ressalva quanto à excepcionalidade do dispositivo em casos de contrato de adesão, especialmente os contratos relativos a direitos do consumidor, questão que será abordada mais profundamente adiante.

Para alguns, a ausência de previsão dessa exceção leva a crer que a cláusula compromissória objetivaria de maneira contrária, criar uma condição de procedibilidade para ações judiciais, tornando-se imprescindível nesse caso, que as partes se submetessem inicialmente à mediação, negligenciando eventual relação de desequilíbrio ou hipossuficiência na condição de consumidor.

De todo modo, essa nova alternativa dada ao particular revela-se muito importante, na medida em que com a crescente insegurança no poder judiciário e o grande volume de conflitos contratuais, os meios alternativos de solução de conflito se tornam os únicos métodos factíveis para a solução de muitas desavenças.

Sendo assim, o que se pretende com este dispositivo é simplesmente estimular as partes que celebraram determinado contrato - seja este de compra e venda, seguro, financeiro, direito do consumidor, relativo à uma empresa familiar, ou até mesmo um pacto antenupcial - a se informarem adequadamente sobre a mediação e decidirem se têm interesse ou não em dela participar ${ }^{36}$, oportunizando o desenvolvimento da mediação como método eficaz e viável de solução de controvérsias contratuais futuras. Como alternativa à cultura do litígio e dos métodos adversariais - aqueles em que a razão é concedida a apenas um dos envolvidos no conflito - a mediação desponta como mecanismo de escolha de particulares. Nesse contexto, os contratantes optam pela previsão contratual de cláusula compromissória de mediação a fim retomarem o controle do processo decisório no surgimento de desavenças contratuais.

Ao debruçar-se sobre o tema, Tânia Almeida conclui que:

\footnotetext{
${ }^{36}$ HALE, 2016, p. 66.
} 
A autoria das soluções devolve aos mediandos o controle do processo decisório sobre suas próprias vidas e possibilita que a solução eleita atenda a seus reais interesses, necessidades e valores. Autores cuidam do que criam, o que torna o cumprimento do acordado na Mediação uma consequência natural e uma ação pautada no compromisso entre os envolvidos ${ }^{37}$.

Como bem expõe Fernanda Tartuce ${ }^{38}$, na esfera contratual, em particular na área relativa ao comércio em geral, verifica-se a propensão acentuada ao desligamento da intervenção estatal na relação privada. Considerando que os contratos representam causa comum de litígio e que os particulares necessitam de soluções rápidas e eficazes para suas contendas, é imprescindível que haja um amplo leque de vias pacíficas para remediar essas situações.

A esse respeito, Kazuo Watanabe explana que:

(...) além de iniciativas legislativas, há também a tendência, que se nota hoje no mercado, de inclusão, principalmente nos contratos internacionais, de cláusula de mediação necessária antes do início de qualquer processo judicial ou de arbitragem. Isso se deve à percepção dos contratantes de que as soluções amigáveis de conflitos atendem melhor aos interesses deles, e também por causa da preocupação deles quanto à demora e ineficiência dos processos judiciais ${ }^{39}$.

Ressalte-se também, que essa cláusula contratual não tem aplicação imediata, uma vez que as partes apenas lançarão mão dela, caso surja um conflito entre elas. Dito de outra forma, ao optarem pela inclusão da referida cláusula, as partes têm interesse em evitar que uma divergência contratual futura e incerta se desdobre imediatamente em longo e penoso processo judicial.

Vale frisar a relevância da mediação em conflitos contratuais, na medida em que as relações interpessoais são dinâmicas e em constante movimentação. Isso quer dizer que as condições previstas em um contrato

\footnotetext{
${ }^{37}$ ALMEIDA, Mediação de Conflitos: Um meio de prevenção e resolução de controvérsias em sintonia com a atualidade. Acesso em: 21 abr. 2016.

${ }^{38}$ TARTUCE, 2016, p. 321.

${ }^{39}$ TARTUCE, Fernanda. Mediação nos conflitos civis. $3^{\text {a }}$ ed. ver. atual e ampl. Rio de Janeiro: Forense. São Paulo: Método, 2016. p. 321 apud WATANABE, Kazuo. Cultura da sentença e cultura da pacificação. p. 685. In: YARSHELL, Flávio Luiz; MORAES, Maurício Zanoide de. (Coord.). Estudos em homenagem à professora Ada Pellegrini Grinover. São Paulo: DPJ, 2005.
} 
estão sujeitas a alterações a qualquer momento, considerando a mudança da realidade. Assim, deve se ter em mente que na produção do contrato são consideradas certas expectativas dos contratantes, que muitas vezes acabam não sendo atendidas integralmente no decorrer da sua implementação.

Desse modo, uma regra estipulada à época da celebração do contrato pode ser tornar inaplicável no momento atual devido às mudanças do comportamento das partes, das condições sociais ou diversos outros fatores, o que acaba por gerar nas organizações um elevado descumprimento de contratos e $\operatorname{acordos}^{40}$.

Nesse sentido Stephen Goldberg destaca que, nos conflitos contratuais, um julgador pode acabar decidindo com base em sua interpretação da linguagem e das intenções quando da celebração do contrato; contudo estas podem ser muito diferentes daquelas existentes no momento do surgimento do problema, e caso as partes possam negociar sozinhas uma solução, a chance de obter um resultado eficaz será maior ${ }^{41}$.

Ao falarmos de contratos que envolvem disputas acerca de fatos ou valor do caso, nos referimos a objeto de índole disponível. Nesse contexto, são grandes as chances de as partes reorganizarem suas posições iniciais para tratar das controvérsias existentes, hipótese em que se recomenda o uso da mediação, pois assim, elementos particulares da relação contratual poderão ser reputados com maior eficácia e detalhamento.

Nessa linha, mostra-se aconselhável o uso da mediação para compor conflitos oriundos de contratos de seguro por exemplo. Considerando as peculiaridades deste tipo de contrato, que possui linguagem específica, demanda um conhecimento aprofundado acerca do tema e exige uma

\footnotetext{
${ }^{40}$ TARTUCE, Fernanda. Mediação nos conflitos civis. $3^{\text {a }}$ ed. ver. atual e ampl. Rio de Janeiro: Forense. São Paulo: Método, 2016. p. 322 apud BRAGA NETO, Adolfo. A Mediação de conflitos nas organizações. Valor Econômico, CIDADE. Cad. E2. p. XXX, 8 out. 2004.

${ }^{41}$ GOLDBERG, Stephen. The Mediation of Grievances under a Collective Bargaining Contract: an alternative do arbitration. 77 Nw. U. L. Rev. 270, 1982. p. 281-305 In: RISKIN, Leonard L. \& WESTBROOK, James E. Dispute Resolution Lawyers. $2^{\mathrm{a}}$ ed. Saint Paul: West Group, 2004. p. 658.
} 
solução rápida, sob pena da produção de danos maiores do que os que se pretendem evitar, a via judicial pode não ser a mais adequada.

Nesse cenário a previsão de cláusula de mediação torna-se muito útil, não por falta do sistema estatal, mas pela necessidade que as partes têm de alcançar um acordo de forma mais célere, ou na impossibilidade deste, de obterem uma decisão proveniente de julgador familiarizado com as peculiaridades do instituto ${ }^{42}$.

Outro campo de aplicação da cláusula compromissória é a mediação comercial. A mediação comercial, na definição de Fernanda Lourenço Levy ${ }^{43}$ é aquela "atinente a conflitos externos que surgem nas relações entre a empresa e seus fornecedores, compradores, etc.", ou seja, uma série de relações de natureza comercial, que a empresa possui de maneira a viabilizar o objetivo final da sua atividade.

Tenha-se em mente que as empresas não se bastam, ou seja, dependem da contratação de parceiros para o fornecimento de serviços e produtos fundamentais para a realização de seu fim.

Levando isso em consideração, Claudia Frankel Grosman e Sandra Regina Olivan Bayer ${ }^{44}$ ponderam que:

\begin{abstract}
A mediação comercial possui um componente extraordinário, nesse ponto: essas relações comerciais típicas da atividade empresarial são objeto de contratos. Esses contratos, por sua vez, possuem, mesmo que somente pró-forma, cláusulas de soluções de disputas. Apesar de no Brasil ainda ser comum, nesses contratos a adoção somente de cláusulas de eleição de foro (nas quais as partes escolhem a Comarca que terá competência territorial para conhecer ação judicial a ser proposta em caso de conflito), esse é o espaço que proporciona a grande oportunidade para mediação comercial.
\end{abstract}

\footnotetext{
${ }^{42}$ ALMEIDA, Tania \& GOMMA, Maurício. Um instrumento de pacificação social. Contratos de seguro: a importância da mediação na solução de conflitos. Disponível em: <http://docvirt.com/docreader.net/DocReader.aspx?bib=cader_segur\&pagfis=304\&pesq >. Acesso em: 10 out. 2016.

${ }^{43}$ GROSMAN, Claudia Frankel \& BAYER, Sandra Regina Garcia Olivan. As Oportunidades da aplicação da Mediação no Âmbito Empresarial. Mediação de Conflitos para Iniciantes, Praticantes e Docentes. Parte II. Cap. 1.3, 2016. p. 388 apud LEVY, Fernanda Rocha Lourenço. Cláusulas Escalonadas - A Mediação Comercial no Contexo da Arbitragem. São Paulo: Editora Saraiva, 2013. p. 130.

${ }^{44}$ Ibid., 2013, p. 130.
} 
Embora a previsão contratual não seja obrigatória, as autoras elucidam que cláusulas especiais para resolução de desavenças contratuais têm sido frequentemente embutidas nos contratos comerciais como cláusulas de arbitragem, de mediação e mistas/escalonadas (cláusulas medarb ou arb-med), o que se exemplificará mais adiante neste capítulo.

Como lecionam Claudia Frankel Grosman e Sandra Regina Garcia Olivan Bayer ${ }^{45}$.

Qualquer breve contrato de compra e venda de um parafuso, por uma empresa, para a fabricação de seus produtos, pode conter uma cláusula de mediação. Mas como foi dito anteriormente, o maior benefício da mediação ocorre nas relações comerciais de longo termo.

Diogo Almeida e Fernanda Pantoja ${ }^{46}$ recomendam a mediação como método adequado ao enfrentamento de litígios acerca desses contratos comerciais de longa duração, nos quais as partes já estabeleceram diálogo prévio e têm o claro interesse de que a relação negocial seja duradoura.

Nesse contexto, os autores destacam que:

É comum a ocorrência de pequenos incidentes e acontecimentos não previstos contratualmente, ou a alteração da situação inicial dos contratantes, que demande um tratamento específico, sob pena de descontinuidade do vínculo. A solução imposta por um terceiro (Estado-juiz ou árbitro) não fomenta a recuperação do diálogo, que foi afetado ou perdido em decorrência do incidente, e, por conseguinte, a solução da questão apresentada encerra um problema passado, mas pode tornar inviável a relação futura.

Dentre os conflitos rotineiros entre duas empresas, que podem ser facilmente resolvidos em demanda simples arbitral ou judicial, cabe ao advogado e ao empresário averiguar quais outras eventuais parcerias entre essas mesmas empresas poderão sofrer com a quebra da relação amigável entre elas.

\section{Segundo Grosman e Bayer:}

\footnotetext{
${ }^{45}$ GROSMAN \& BAYER, 2016. p. 388

${ }^{46}$ ALMEIDA, Diogo A. Rezende de Almeida \& PANTOJA, Fernanda Medina. Áreas de atuação da Mediação de Conflitos. In: PELAJO, Samantha et al.. (Coord.). Mediação de Conflitos para Iniciantes, Praticantes e Docentes. Parte I. Cap. 6. Salvador: Ed. JusPodvim, 2016. p. 120.
} 
Essas relações valiosas para a atividade empresarial beneficiam-se sobremaneira pela previsão contratual da realização de mediação anterior à busca de uma solução adjudicada para o conflito, seja judicial, seja arbitral. Nesse sentido, muitas Câmaras arbitrais, entre nós, já possuem regulamento próprio para procedimento de mediação e amplo quadro de mediadores, de tal forma que os contratos comerciais, agora, já podem contar com a opção da mediação institucional, regulada pela Câmara, assim como ocorre na arbitragem.

Outro terreno bastante fértil para a mediação é o campo da recuperação judicial, falência, ou, ainda, nos conflitos decorrentes dos processos de insolvência, sendo a mediação totalmente viável nesse cenário, eis que de acordo com o enunciado do art. $3^{\circ}$ da Lei $n^{\circ} 13.140 / 2015$, "pode ser objeto de mediação o conflito que verse sobre direitos disponíveis ou sobre direitos indisponíveis que admitam transação".

Destaca-se que inexiste óbice para a inclusão de cláusula de mediação em recuperação judicial, eis que: (i) os conflitos daí decorrentes ficam restritos a direitos pecuniários dos credores da empresa devedora; e (ii) o plano de recuperação judicial dirige-se a um acordo de vontades em observância ao princípio da autonomia das vontades e da isonomia.

Conforme leciona Ana Tereza Basílio ${ }^{47}$ :

Incluída a cláusula de mediação no plano de recuperação aprovado em assembleia e homologado pelo Juízo, as questões relativas ao cumprimento do plano, notadamente aquelas que surgirem após o prazo bienal previsto no caput do art. 61 da Lei 11.101/2005, serão objeto de mediação, aplicando-se, tanto quanto possível, as normas do arts. 16 e 23 da Lei de Mediação.

Ademais, a mediação não se mostra frutífera somente no tratamento de aspectos objetivos do negócio jurídico, mas também permite considerar fatores subjetivos da relação interpessoal para superar as adversidades. Assim, quando ocorre a perda do consenso na celebração do negócio jurídico, as partes que incluíram a cláusula de mediação no contrato desfrutarão de um ambiente propício para o restabelecimento da

${ }^{47}$ BASÍLIO, Ana Tereza. A possibilidade de inclusão de cláusula de mediação em plano de Recuperação Judicial. Jota. 24 Set. 2016. Disponível em: <http://jota.info/possibilidade-deinclusao-de-clausula-de-mediacao-em-plano-de-recuperacao-judicial>. Acesso em: 27 out. 2016. 
comunicação, do diálogo e da relação logo na primeira reunião de mediação.

Lembre-se que o objetivo primordial da mediação não é necessariamente a celebração de um acordo, que é mera consequência, mas sim o restabelecimento da comunicação, a preservação do relacionamento entre as partes, a possível prevenção de conflitos e a inclusão e pacificação social.

Considerando que a seara contratual sempre constituiu o ambiente da realização de meios diferenciados de tratamento de controvérsias é importante assinalar os critérios perquiridos pelas partes contratantes na escolha da mediação. Estes critérios incluem: (i) desejo de preservar relações futuras; (ii) ênfase no trato futuro; (iii) necessidade de evitar decisões que impliquem ganhar ou perder totalmente; (iv) contendores desejam ter controle sobre o processo; (v) a disputa tem múltiplas partes e questões; (vi) ausência de direitos legais $\operatorname{claros}^{48}$.

Como bem pontua Tânia Almeida, a inserção da cláusula compromissória de mediação em muitos países como termo de autocomposição de controvérsias nos contratos comerciais, financeiros, securitários e empresariais, constitui hoje para aquelas culturas indicador da possibilidade de soluções satisfatórias, conferindo total credibilidade ao instrumento e aos contratos que a incluem ${ }^{49}$.

Um dos critérios mais vantajosos da mediação diz respeito à postura protagonista das partes acerca do deslinde da controvérsia, o que é importantíssimo no ramo contratual no qual impera a autonomia privada. Assim, nos moldes da mediação, quem constrói o conflito é o mais habilitado para desconstruí-lo.

\footnotetext{
48 TARTUCE, 2016, p. 324.

49 ALMEIDA, Tânia. Mediação na virada do milênio. Mediare. 31 mai. 1999. Disponível em: <http://www.mediare.com.br/2016/02/29/mediacao-na-virada-de-milenio/>. Acesso em: 19 abr. 2016.
} 
Sendo assim, resta evidente que a mediação desponta como ferramenta valiosa para fazer nascer um novo contrato que melhor reflete a vontade das partes, na qual os contratantes possam definir em conjunto e de forma consensual o destino da controvérsia, encontrando saídas criativas para questões rotineiras que possam advir em contratos de prestação de serviços ou fornecimento de produtos por exemplo.

Inserida a cláusula compromissória de mediação, quando do surgimento do conflito, o mediador deverá informar as partes acerca dos princípios que regem o instituto logo na primeira reunião, em conformidade com o art. $2^{\circ}, \S 1^{\circ}$ do Código de Conduta para Mediadores, anexo à Resolução no 125/2010 do CNJ. Impende ressaltar, que o art. 14 da Lei ${ }^{\circ}$ 13.140, impõe ao mediador nesta sessão inaugural a obrigação de alertar as partes acerca do princípio da confidencialidade que norteia a mediação ${ }^{50}$.

Sendo assim, ao acrescerem a cláusula de mediação no contrato, as partes se comprometem a comparecer à primeira reunião de mediação, e estarão diante de uma importante fase no processo, com caráter eminentemente informativo, conhecida como pré-mediação.

Nas palavras de Tania Almeida, nesta etapa:

No que tange aos mediandos, estes recebem informações sobre o processo de autocomposição visando: (i) elencar claramente os temas que os trazem à mediação; (ii) possibilitar a escolha consciente da mediação como meio de resolução de conflito e/ou das questões existentes; (iii) identificar se encontram em si mesmos disponibilidade para rever posições rígidas ou competitivas; (iv) trabalhar focados na busca de soluções de benefício mútuo; (v) reconhecer a possibilidade de empenho na observância dos propósitos e princípios éticos do instituto $^{51}$.

Na visão de Fernanda Tartuce, a crescente inclusão de cláusulas contratuais prevendo a adoção da mediação como etapa inicial na abordagem de controvérsias revela que a busca de saídas conjuntas como

\footnotetext{
${ }^{50}$ Art. 14. No início da primeira reunião de mediação, e sempre que julgar necessário, o mediador deverá alertar as partes acerca das regras de confidencialidade aplicáveis ao procedimento.

${ }^{51}$ ALMEIDA, Tania. Caixa de ferramentas em mediação: aportes práticos e teóricos. São Paulo: Dash, 2014. p. 37.
} 
fase precedente à instauração de litígio tem sido considerada uma opção interessante ao trato contencioso ${ }^{52}$.

Ao embutirem cláusula compromissória de mediação no contrato, os contratantes podem eleger uma cláusula simples ou escalonada, sendo neste último caso atrelada à utilização prévia ou posterior de outros mecanismos de solução de conflito, tais como a arbitragem.

Acerca das cláusulas escalonadas, Fernanda Rocha Lourenço Levy explica que estas são meios combinados e multietapas de resolução de controvérsias $^{53}$, sendo as mais comuns, estipulações contratuais de med/arb e arb/med, que preveem respectivamente a mediação seguida da arbitragem, ou a arbitragem seguida da mediação.

Como bem pontua Petrônio Calmon, mediação/arbitragem (med/arb) ocorre quando as partes concordam em realizar a mediação, mas, caso essa não reste frutífera, seja desde logo praticada a arbitragem, normalmente por outra pessoa da mesma entidade ou escritório que realiza a mediação. Já na arb/med sucede o contrário, ou seja, realiza-se o procedimento da arbitragem chegando-se à prolação da sentença. $\mathrm{O}$ árbitro anuncia às partes que a sentença está pronta, mas não a revela, depositando-a em local seguro e inviolável. Com isso proporciona que sejam iniciadas as tratativas com vistas à obtenção da autocomposição (mediação). Caso não se logre o acordo, revela-se a sentença antes prolatada ${ }^{54}$.

Nesse contexto, Aldemar Motta $\mathrm{Jr}^{55}$ sugere quatro hipóteses de cláusulas de mediação a ser adotadas pelas partes:

Na primeira, uma cláusula de mediação isolada (ou simples), em que se deixa em aberto a alternativa que poderá ser adotada caso não se obtenha solução

\footnotetext{
${ }^{52}$ TARTUCE, 2016, p. 321.

${ }^{53}$ LEVY, Fernanda Rocha Lourenço. Arbitragem, mediação e a cláusula escalonada. Jornal Carta Forense, 2014. Disponível em: <http://www.cartaforense.com.br/conteudo/entrevistas/arbitragemmediacao-e-a-clausula-escalonada/13774>. Acesso em: 10 out. 2016.

${ }^{54}$ CALMON, Petronio. Fundamentos da mediação e conciliação. $3^{\mathrm{a}}$ ed. Brasilia, DF: Gazeta Jurídica, 2015. p. 93.

${ }^{55}$ MOTTA JR, Aldemar de Miranda. Manual de Mediação de Conflitos para Advogados. BrasíliaDF: Ministério da Justiça, 2014. p. 48-49.
} 
consensuada. Na segunda, uma cláusula escalonada mediação e arbitragem (MedArb). Na terceira, uma cláusula escalonada mediação-judiciário (Med-Jud). Enfim, na quarta hipótese, uma cláusula escalonada MedArb, detalhada, para situações que podem envolver pessoas de países e línguas diferentes. Com efeito, "Pacta sunt servanda"!

Assim, é inequívoco que conquanto a arbitragem - diferentemente da mediação - seja um método heterocompositivo de solução de conflitos, tendo em vista que o poder decisório é imposto ao árbitro e não às partes, nada impede que as partes celebrem um contrato e incluam cláusula que favoreça a utilização sucessiva destes dois mecanismos para a solução da controvérsia.

Nesse contexto, interessante notar que em estudo norte-americano, no qual foram analisadas 449 disputas carreadas pelos quatro maiores fornecedores de serviços de meios alternativos de solução de conflitos nos Estados Unidos; feita a comparação entre mediação e arbitragem constatouse que a mediação é substancialmente mais econômica, célere e preferida pelo público ${ }^{56}$.

Diante do exposto, percebe-se a relevância da cláusula de mediação, considerando que ela pode causar um enorme impacto positivo na relação contratual, devolvendo às partes a autonomia da vontade na resolução de conflitos contratuais.

Ademais, é nítida a flexibilidade no entorno da redação da cláusula, que permite a interação da mediação com outros mecanismos, bem como uma voz ativa das partes na definição dos critérios que vão permear a mediação conforme se verá adiante.

\footnotetext{
${ }^{56}$ BRETT, Jeanne \& BARSNESS, Zoe. The Effectiveness of Mediation: An Independent Analysis of Cases Handled by Four Major Service Providers. 12 Neg. J 259, 1996. p. 260-267 In: RISKIN, Leonard L. \& WESRBROOK, James E. Dispute Resolution and Lawyers. $2^{\mathrm{a}}$ ed. Saint Paul: West Group, 2004. p. 448.
} 


\section{CAPÍTULO 3 - REQUISITOS DA CLÁUSULA COMPROMISSÓRIA DE MEDIAÇÃO}

O marco legal da mediação estipulou no art. 22 da Lei $n^{\circ} 13.140$ de 2015 uma série de requisitos mínimos que devem ser observados na previsão contratual da mediação. Estas condições variam de acordo com a situação e tem o escopo de orientar as partes na redação de uma cláusula compromissória condizente com os princípios que norteiam o instituto, de forma a impulsioná-las a comparecer à primeira reunião de mediação.

Os quatro requisitos primordiais que devem ser contemplados no contrato são os seguintes: (i) prazo mínimo e máximo para a realização da primeira reunião de mediação; (ii) local de realização da primeira reunião de mediação; (iii) critérios de escolha do(s) mediador(res); (iv) penalidade em caso de não comparecimento à primeira reunião de mediação.

Dessa forma, diante de cláusula compromissória cheia ou completa, os requisitos poderão ser definidos livremente pelas partes contratantes no momento redação da cláusula ${ }^{57}$, dando-lhes grande autonomia nesta etapa.

Alternativamente, as partes poderão omitir-se, incluindo no bojo do contrato uma cláusula compromissória vazia, isto é, incompleta, sem menção a informações relevantes para a realização da primeira reunião de mediação. Nesse caso o legislador impõe a observância de critérios estreitos, limitando aqui o poder das partes.

Um terceiro cenário admissível seria o das partes se absterem de qualquer especificação. Para isso, basta que façam referência ao regulamento de uma instituição idônea prestadora de serviços de mediação,

\footnotetext{
${ }^{57}$ Art. 22. A previsão contratual de mediação deverá conter, no mínimo:

I - prazo mínimo e máximo para a realização da primeira reunião de mediação, contado a partir da data de recebimento do convite;

II - local da primeira reunião de mediação;

III - critérios de escolha do mediador ou equipe de mediação;

IV - penalidade em caso de não comparecimento da parte convidada à primeira reunião de mediação.
} 
conforme a exegese do $\S 1^{\mathrm{o}}$ do referido diploma legal ${ }^{58}$. Nesse caso, a instituição de mediação definirá no regulamento critérios exatos para a escolha de mediador e realização da primeira reunião de mediação.

As instituições e câmaras prestadoras de serviços de mediação possuem seus próprios diplomas normativos. Alguns exemplos incluem o “Roteiro de Mediação" do Centro de Arbitragem e Mediação da Câmara de Comércio Brasil-Canadá; o "Regulamento de Mediação e Conciliação" e o “Código de Ética dos Mediadores e Conciliadores" da Câmara de Mediação e Conciliação da FIESP - Federação das Indústrias do Estado de São Paulo.

Conquanto não haja modelos uniformes, aplicáveis tanto às mediações ad hoc (realizadas por mediadores escolhidos livremente pelas partes e desvinculados de qualquer entidade) quanto às mediações conduzidas por institutos de mediação, existem algumas diretrizes comuns emanadas pelo Poder Público.

Nesse contexto, Fernanda Pantoja e Marcelo Oliveira ${ }^{59}$ esclarecem que a cláusula compromissória é diretriz básica que merece constar de um Regulamento Modelo, a partir da análise da lei brasileira e dos conjuntos normativos das principais instituições nacionais e estrangeiras dedicadas à mediação.

Diante da importância de se estimularem os contratantes a prever cláusula de mediação em suas convenções, é interessante que o Regulamento da instituição eleita proponha uma redação para tal dispositivo.

Conclui-se, portanto, que de forma geral é dada grande flexibilidade aos contratantes no momento de incorporação da cláusula compromissória,

\footnotetext{
$58 \S 1^{\circ}$ A previsão contratual pode substituir a especificação dos itens acima enumerados pela indicação de regulamento, publicado por instituição idônea prestadora de serviços de mediação, no qual constem critérios claros para a escolha do mediador e realização da primeira reunião de mediação.

59 PANTOJA, Fernanda Medina \& OLIVEIRA, Marcello. Regulamentação da Mediação de Conflitos: Código de Ética In: PELAJO, Samantha et al.. (Coord.). Mediação de Conflitos para Iniciantes, Praticantes e Docentes. Parte I. Cap. 19. Salvador: Ed. JusPodvim, 2016. p. 313.
} 
para que o termo reflita de forma fiel as necessidades e peculiaridades da relação jurídica das partes.

Na síntese de Fernanda Tartuce ${ }^{60}$, o conteúdo mínimo da cláusula de mediação consta no art. 22 da Lei no 13.140 de 2015, que também permite que as partes façam referência ao regulamento de uma instituição idônea de serviços de mediação; sendo a cláusula omissa, há critérios legais para a realização da mediação.

O que se propõe em seguida é pormenorizar cuidadosamente as implicações advindas da definição dos quatro requisitos mencionados acima. Assim, para a melhor compreensão do leitor, a autora optou por dividir os requisitos que serão abordados em subitens.

\subsection{Prazo mínimo e máximo para a realização da primeira reunião de mediação}

Conforme se depreende do inciso I do art. 22 da Lei $\mathrm{n}^{\circ} 13.140$, na hipótese de cláusula compromissória cheia ou completa, o primeiro requisito a ser observado é o prazo mínimo e máximo para a realização da primeira reunião de mediação, que começa a fluir a partir da data do recebimento do convite de mediação.

Ao atribuir aos contratantes a prerrogativa de estipular um limite temporal para a realização da primeira reunião, o legislador habilita os eventuais mediandos a moldarem a duração do procedimento, flexibilizando-o para melhor atender à conveniência das partes.

Dessa forma, é facultada aos contratantes a indicação tanto de prazo mais elástico, como de prazo mais abreviado. A título de exemplo, as partes podem optar pelo limite temporal de 4 meses contados do recebimento do convite de mediação, por entenderem que um prazo alongado se adequa satisfatoriamente às suas necessidades.

\footnotetext{
${ }^{60}$ TARTUCE, 2016, p. 322.
} 
Ao contrário, se preferirem, os contratantes podem eleger o curto prazo de 5 dias contados do recebimento do convite à primeira reunião de mediação, julgando-o como o mais apropriado para o encaixe em suas respectivas rotinas.

Assim, resta evidente que a norma legal prima por um dos princípios mais caros à mediação, qual seja: a autonomia da vontade, empoderando as partes a elegerem o lapso temporal, que melhor se enquadra dentro de sua realidade.

Ademais, ao estabelecer que as partes fixem um limite temporal para o início do procedimento o legislador busca evitar que o processo se alongue indefinidamente no tempo, sem previsão de término, tal como acontece na maioria das ações judiciais.

Portanto, a finalidade do prazo é imprimir maior velocidade ao procedimento, alçando o instituto da mediação como um método de referência em celeridade na resolução do conflito, e impedindo que o processo se arraste, ocasionando a demora no início das conversas.

Caso os contratantes não fixem o lapso temporal à sua maneira, tampouco indiquem o regulamento aplicável nos termos apontados, estaremos diante de cláusula compromissória "em branco", incompleta ou vazia.

Nessa hipótese, consoante a inteligência do parágrafo $2^{\circ}$, inciso I da Lei $\mathrm{n}^{\mathrm{o}} 13.140$, o legislador mitiga a autonomia das partes, ao impor o prazo mínimo de dez dias úteis e prazo máximo de três meses para a realização da primeira reunião, contados do recebimento do convite de mediação.

Note-se que nesse cenário, o legislador primou novamente pela celeridade do procedimento ao impor um limite temporal conciso no caso de omissão dos contratantes.

Assim, entendeu-se que o mínimo de 10 dias úteis do recebimento do convite de mediação seria um prazo razoável para as partes se munirem de 
todas as informações necessárias acerca do procedimento. Da mesma maneira, deduziu-se que três meses do recebimento do convite, seria o prazo suficiente para aparelhar os contratantes com todos os dados necessários e evitar o retardamento do primeiro encontro de mediação.

\subsection{Local da primeira reunião de mediação}

O segundo requisito mínimo para a previsão contratual da cláusula compromissória de mediação é a definição do local para a realização da primeira reunião do procedimento.

Neste sentido, o inciso II do art. 22 da Lei $\mathrm{n}^{\mathrm{o}} 13.140$ prevê que as partes têm o direito de convencionar livremente o local onde pretendem realizar o primeiro encontro. Convém ressaltar que o espaço eleito deve ser propício para a troca de informações confidenciais, tendo em vista a importância do princípio da confidencialidade que rege o procedimento, tal como explanado neste estudo.

Acerca do tema, Tânia Almeida relembra que:

O pilar da confidencialidade na mediação confere uma moldura de confiança para as partes, possibilitando-lhes aceitar o convite de ter na boa fé um norteador para a sua postura durante o processo ${ }^{61}$.

Desse modo, é recomendável que as partes atentem para o fato de que o ambiente designado para abrigar a primeira conversa não deve ser um espaço de frequente circulação de pessoas, a fim de que seja preservada a confidencialidade da reunião.

Caso os contratantes não definam a sede da primeira reunião de mediação, tampouco optem por regulamento para reger o procedimento, a norma legal se limita a sugerir que o encontro se dê em "local adequado a

\footnotetext{
${ }^{61}$ ALMEIDA, Tania. Mediação e Conciliação: Duas práticas distintas, dois paradigmas diversos. Mediare. Disponível em: <http://www.mediare.com.br/2016/03/02/mediacao-e-conciliacao-doisparadigmas-distintos-duas-praticas-diversas/>. Acesso em: 21 abr. 2016.
} 
uma reunião que possa envolver informações confidenciais", consoante leitura do $\S 2^{\circ}$, inciso II da Lei de Mediação.

Percebe-se, que o legislador abre margem para dúvida e diversas interpretações, pois apenas aconselha que o local deva ser apropriado para este fim, delegando inteiramente o poder de escolha às partes. Dito de outra forma, conquanto o dispositivo oriente o contratante no sentido de eleger um local propício à troca de dados sigilosos, a Lei não define o que seria um local apropriado.

Portanto, cabe exclusivamente às partes, no exercício do seu bom senso e ponderação, escolherem um ambiente favorável ao intercâmbio de informações privadas, privilegiando-se a autonomia da vontade das partes.

\subsection{Critérios de escolha do(s) mediador(es)}

A previsão contratual da cláusula compromissória de mediação deverá compreender necessariamente os critérios de escolha do mediador ou equipe de mediação, consoante o inciso III do art. 22 da Lei de Mediação. $\mathrm{O}$ que se pretende com essa exigência, é que as partes tenham especial atenção com a escalação de determinado mediador ou equipe de mediação.

Ou seja, é recomendável que os contratantes tenham cautela e depreendam um esforço mútuo para eleger um terceiro imparcial que satisfaça a necessidade de todos caso surja uma desavença, explicitando na redação do termo que constará do contrato, os parâmetros e fatores levados em conta na designação do(s) mediador(es).

Por óbvio, cumpre destacar que havendo indicação de regulamento de instituição de mediação, os critérios de escolha do mediador ou equipe de mediação deverão constar no regulamento da própria entidade, conforme o $\S 1^{\circ}$ do art. 22 da Lei $n^{\circ} 13.140$ de 2015. 
$\mathrm{Na}$ hipótese de cláusula "em branco", o $§ 2^{\circ}$, inciso III do art. 22, socorre a omissão das partes ao exigir a elaboração de uma lista com cinco nomes de mediadores capacitados, suas informações de contato e referências profissionais. De acordo com o comando do dispositivo, facultase à parte convidada à primeira reunião de mediação, a escolha expressa de qualquer um dos cinco mediadores listados. Caso a parte convidada permaneça em silêncio e não manifeste qualquer preferência, o primeiro nome listado na cláusula será tido como aceito.

Em que pese o dispositivo demande a capacitação do mediador extrajudicial, a Lei não definiu expressamente qual a capacitação exigível a um mediador extrajudicial como fez com o mediador judicial ${ }^{62}$. Nesse sentido, a Lei $\mathrm{n}^{\circ} 13.140$ de 2015 , se limita a esclarecer que para funcionar como mediador extrajudicial, o profissional deve ser pessoa capaz e possuir a confiança das partes, independentemente de integrar qualquer instituição de mediação, conforme se depreende do art. $9^{\circ}$ do diploma legal em referência ${ }^{63}$.

Quanto a esse ponto, Alexandre Assed e Larissa Davidovich lembram que houve de início, discussão em torno da obrigatoriedade de realização de curso teórico e de período de prática pelo mediador. Considerando que o referido diploma legal define em seu art. $1^{\circ}$ a mediação como "atividade técnica", insta supor que é imprescindível a capacitação técnica do terceiro imparcial na condução da mediação extrajudicial.

Portanto:

Considerando o disposto no artigo, e diante da interpretação sistemática da Lei, pode-se entender que para realizar a mediação extrajudicial, deverá o mediador

\footnotetext{
${ }^{62}$ Art. 11. Poderá atuar como mediador judicial a pessoa capaz, graduada há pelo menos dois anos em curso de ensino superior de instituição reconhecida pelo Ministério da Educação e que tenha obtido capacitação em escola ou instituição de formação de mediadores, reconhecida pela Escola Nacional de Formação e Aperfeiçoamento de Magistrados - ENFAM ou pelos tribunais, observados os requisitos mínimos estabelecidos pelo Conselho Nacional de Justiça em conjunto com o Ministério da Justiça.

63 Art. 9o Poderá funcionar como mediador extrajudicial qualquer pessoa capaz que tenha a confiança das partes e seja capacitada para fazer mediação, independentemente de integrar qualquer tipo de conselho, entidade de classe ou associação, ou nele inscrever-se.
} 
estar capacitado tecnicamente tendo realizado curso teórico e adequado período de prática ${ }^{64}$.

Ainda nesse tema, Tânia Almeida esclarece que:

A competência (do mediador) é princípio ético especialmente referido à habilidade para conduzir o processo de Mediação. Por esse motivo, a capacitação prévia é exigência para essa prática. Mediadores não necessitam possuir especial conhecimento na matéria que é objeto da disputa - mas sim o suficiente para formular perguntas -, uma vez que não atuarão deliberando ou sugerindo. São os mediandos aqueles que deverão ser instruídos a buscar especial conhecimento na matéria. $\mathrm{O}$ especial conhecimento do mediador deve dizer respeito à condução da dinâmica da Mediação ${ }^{65}$.

Tendo em vista a interdisciplinaridade ínsita à mediação, que utiliza aportes vindos da psicologia, advocacia e outras áreas, os mediadores vêm dos mais diversos campos profissionais. A maioria dos mediadores possui formação jurídica, contudo muitos são profissionais de outras áreas como administradores, psicólogos, assistentes sociais, sociólogos, engenheiros, entre outros.

Considerando a multidisciplinariedade do instituto, Zuleica Meurer destaca que a mediação demanda um conhecimento não apenas jurídico, mas psicológico, sociológico, terapêutico, comunicativo, afetivo e negocial. Não há como ocultar as demais ciências, pois o conflito será um tanto melhor resolvido por mediadores, que tenham vivência, competência e conhecimento acerca da matéria a ser debatida, não importando se é psicólogo, médico ou advogado ${ }^{66}$.

Nesse contexto, para orientar a escolha do mediador, o presidente do Tribunal de Justiça Desportiva do Rio de Janeiro Antonio Vanderler de Lima aconselha a realização de consulta aos quadros da OAB e das instituições idôneas que operam a mediação, como as Câmaras de Mediação

\footnotetext{
${ }^{64}$ ASSED \& DAVIDOVICH In: PELAJO, et al.. (Coord.), 2016, p. 345.

${ }^{65}$ ALMEIDA, Mediação de Conflitos: Um meio de prevenção e resolução de controvérsias em sintonia com a atualidade. Acesso em: 21 abr. 2016.

${ }^{66}$ MEURER, Zuleica Maria. Mediação: uma proposta de solução de conflitos a ser implantada no Brasil. Âmbito Jurídico. 30 jun. 2008. Disponível em: <http://www.ambitojuridico.com.br/site/index.php?n_link=revista_artigos_leitura\&artigo_id=2987>. Acesso em: 15 abr. 2016.
} 
e Arbitragem e os Centros de Administração de Conflitos, para melhor escolha do mediador ${ }^{67}$.

\subsection{Penalidade em caso de não comparecimento à primeira reunião de mediação}

O quarto e último requisito mínimo para a inserção de cláusula compromissória em um contrato é a previsão de uma penalidade em caso de não comparecimento à primeira reunião de mediação, que merece especial atenção em razão da controvérsia que suscita.

Havendo previsão contratual completa, o inciso IV, do art. 22 da Lei $\mathrm{n}^{\mathrm{o}} 13.140$ dispõe que as partes têm autonomia para fixarem a sanção que julgarem mais adequada a ser imputada à parte que não comparecer à primeira reunião de mediação.

É inequívoco que o legislador zelou novamente pelo princípio da autonomia da vontade ao delegar às partes o poder de deliberação e decisão acerca da punição da parte faltante. Nesse contexto, as partes têm um amplo espectro de escolha, podendo estipular desde uma sanção branda, até uma penalidade mais rigorosa, de acordo com a sua própria volição.

Caso os contratantes não definam na cláusula de mediação a condenação a ser aplicada, tampouco indiquem o regulamento de instituição idônea prestadora de serviços de mediação para suprir a omissão, o inciso IV do art. 22 da Lei $n^{\circ} 13.140$ de $2015^{68}$ prevê uma pena pecuniária de $50 \%$ das custas e honorários sucumbenciais caso a parte convidada que não

\footnotetext{
${ }^{67}$ LIMA, Antonio Vanderler de. A integração entre a sistemática de resolução de conflitos $e$ o novo Código de Processo Civil. Editora JC. 20 jul. 2016. Disponível em: $<$ http://www.editorajc.com.br/2016/07/a-integracao-entre-a-sistematica-de-resolucao-de-conflitose-o-novo-codigo-de-processo-civil/>. Acesso em: 20 set. 2016.

${ }^{68}$ Art. 22. A previsão contratual de mediação deverá conter, no mínimo: (...)

IV - o não comparecimento da parte convidada à primeira reunião de mediação acarretará a assunção por parte desta de cinquenta por cento das custas e honorários sucumbenciais caso venha a ser vencedora em procedimento arbitral ou judicial posterior, que envolva o escopo da mediação para a qual foi convidada.
} 
compareceu à primeira reunião saia vitoriosa de ação ou procedimento arbitral posterior, que envolva a matéria da mediação.

Conforme ensinam Hale, Pinho e Cabral, essa mesma sanção deve ser também aplicável à parte que ajuizar diretamente a ação judicial ou requerer a instauração de arbitragem sem atender à cláusula compromissória de mediação ${ }^{69}$.

Forçoso reconhecer que a imposição de uma sanção ao não comparecimento da parte convidada à primeira reunião se deve ao fato de que essa primeira reunião é obrigatória para as partes que preveem cláusula compromissória de mediação no bojo do contrato, consoante o $\S 1^{\circ}$, art. $2^{\circ}$ da Lei $n^{\circ} 13.140$ de $2015^{70}$.

Nesse contexto, é importante lembrar, em interpretação literal do $\S 2^{\circ}$ do art. $2^{\circ}$ da Lei $n^{\circ} 13.140$ de $2015^{71}$, que o instituto da mediação não é compulsório e a sua permanência não deve ser imposta às partes. A obrigatoriedade da mediação fere a natureza do procedimento, que em essência é marcado pela voluntariedade e espontaneidade.

Neste sentido, Humberto Pinho e Michele Paumgartten ${ }^{72}$ expõe que:

Transformá-la numa etapa obrigatória seja no momento pré-processual ou incidental tem a finalidade de servir a propósitos meramente estatísticos, e que estão longe de atender às necessidades do cidadão. Mediar não se resume a silenciar o outro interessado no acordo ou fazer com o que conflito vá embora. Isso não permite o retorno ao status quo anterior à origem do conflito. A razão da mediação passa a ser o fim da controvérsia, a pacificação ao invés da paz, colocando-se de lado a lógica relacional que lhe é basilar.

\footnotetext{
${ }^{69}$ HALE, 2016, p. 66.

${ }^{70}$ Art. $2^{\mathrm{a}}$ A mediação será orientada pelos seguintes princípios (...).

$\S 1^{\mathrm{a}} \mathrm{Na}$ hipótese de existir previsão contratual de cláusula de mediação, as partes deverão comparecer à primeira reunião de mediação.

${ }^{71}$ Art. $2^{\mathrm{a}}$ A mediação será orientada pelos seguintes princípios: (...).

$\S 2^{a}$ Ninguém será obrigado a permanecer em procedimento de mediação.

${ }^{72}$ PINHO, Humberto Dalla Bernardina de. (org.). A Nova Lei de Mediação Brasileira Comentários ao Projeto de Lei n ${ }^{\circ}$ 7169/14. Revista Eletrônica de Direito Processual. Ano 8. Volume Especial. Rio de Janeiro, 2014. Disponível em: <https://www.academia.edu/8676991/Revista_Eletrônica_de_Direito_Processual_REDP_A_NO VA_LEI_DE_MEDIAÇÃO_BRASILEIRA_COMENTÁRIOS_AO_PROJETO_DE_LEI_N_7.16 914>. Acesso em: 03 mai. 2016 apud PINHO, Humberto Dalla Bernardina de \& PAUMGARTTEN, Michele Pedrosa. A institucionalização da mediação é a Panacea para o acesso à justiça?. Disponível em: <http://www.publicadireito.com.br/artigos/?cod=0fd4b8a8354a77a3>. Acesso em: 31 jul. 2014.
} 
Sendo assim, embora o instituto seja de permanência facultativa, o legislador optou por reforçar a obrigatoriedade de comparecimento à primeira reunião em caso de previsão de cláusula compromissória de mediação, a fim de estimular as partes à oportunizarem a mediação, e não a forçar a participação no procedimento.

A respeito dessa questão, o Relator do Projeto de Lei 7169/14 que deu origem à Lei $n^{\circ} 13.140$ de 2015, Dep. Federal Sérgio Zveiter ${ }^{73}$, esclarece que a cláusula de mediação inserida no $\$ 2$, do artigo $2^{\circ}$ estabelece apenas a obrigatoriedade de se tentar mediar um conflito antes de levá-lo ao Poder Judiciário. O relator chama atenção para o fato de que apenas o comparecimento à primeira reunião é compulsório, e que nesta ocasião a parte será informada sobre o que é a mediação e de que forma ela se desenvolve.

Assim, o deputado afirma que ninguém será obrigado a efetivamente, chegar a um acordo, e que essa imposição de comparecimento à primeira reunião de mediação é prática muito bem-sucedida em diversos países.

A relevância dessa disposição justifica a sua transcrição a seguir:

(...) a primeira reunião de mediação é a oportunidade necessária para que o mediador use suas técnicas e amplie a compreensão das partes acerca dos benefícios e alcances da mediação. Só então a escolha do método (mediação, conciliação, arbitragem ou judiciário) pode ser considerada devidamente informada. Se, a partir daí as partes não desejarem dar prosseguimento ao procedimento de mediação, o princípio da voluntariedade e autodeterminação prevalecerá e não serão obrigadas a negociar o conflito em mediação. Nos países onde uma primeira reunião de mediação é obrigatória, muitas partes e advogados relatam que não acreditavam nas possibilidades de acordo, mas, uma vez obrigados a comparecer, decidiram usar a oportunidade para tentar uma solução consensual.

É inequívoco, portanto, que ao contrário de compelir as partes a seguirem no procedimento, o que certamente desvirtuaria o instituto, o que se pretende com este dispositivo é dar força e eficácia à cláusula

\footnotetext{
${ }^{73}$ BRASIL. Câmara dos Deputados. Disponível em: $<\mathrm{http} / / / \mathrm{www}$. camara.gov.br/proposicoesWeb/prop_mostrarintegra?codteor=1260500\&filename $=\mathrm{T}$ ramitacao-PL+7169/2014>. Acesso em: 25 set. 2016.
} 
compromissória, ao vincular a sua inserção ao comparecimento obrigatório à primeira reunião de mediação.

Quanto à eventual alegação de inconstitucionalidade, o Deputado Sérgio Zveiter afirma que:

Por força do princípio da inafastabilidade da jurisdição, assevera-se que a proposta não exclui a apreciação do conflito pelo Poder Judiciário. No entanto, caso haja clausula de mediação estabelecida em contrato, ela funcionará como uma prejudicial formal que deverá ser vencida antes de se propor ação judicial.

Para Humberto Pinho ${ }^{74}$, mesmo com a previsão desta obrigatoriedade:

Não se afasta a natureza facultativa do instituto, pois se remete à opção exercida em momento prévio, quando da consecução do negócio jurídico, cujas repercussões quanto ao seu modo de formação, execução e extinção podem ser direcionadas à mediação.

Sob a ótica do legislador, o comparecimento à primeira reunião de mediação, em obediência à cláusula compromissória, constitui um dever moral das partes, eis que as mesmas se comprometeram a tentar mediar em caso de controvérsia contratual e despenderam esforço para incluir uma cláusula de mediação vinculante no bojo do contrato.

Como bem pontua Fernanda Tartuce ${ }^{75}$, a Lei de Mediação revela comprometimento com a boa-fé objetiva ao obrigar as partes que contemplaram no contrato a comparecer à primeira reunião consensual embora reconheça não ser obrigatório que elas permaneçam no procedimento.

\footnotetext{
${ }^{74}$ PINHO, Humberto Dalla Bernardina de. (org.). A Nova Lei de Mediação Brasileira Comentários ao Projeto de Lei n ${ }^{\circ} 7169 / 14$. Revista Eletrônica de Direito Processual. Ano 8. Volume Especial. Rio de Janeiro, 2014. Disponível em: <https://www.academia.edu/8676991/Revista_Eletrônica_de_Direito_Processual_REDP_A_NO VA_LEI_DE_MEDIAÇÃO_BRASILEIRA_COMENTÁRIOS_AO_PROJETO_DE_LEI_N_7.16 914>. Acesso em: 03 mai. 2016.

${ }^{75}$ TARTUCE, 2016, p. 321.
} 
Fernanda Pantoja e Marcello Oliveira ${ }^{76}$, chamam atenção para o fato de que:

\begin{abstract}
Não se exige das partes a sua adesão ao procedimento, mas tão somente a sua presença na reunião inicial. Trata-se de uma importante oportunidade para o desenvolvimento da mediação, quando as partes podem se convencer das sias vantagens e da sua pertinência para solucionar o caso concreto.
\end{abstract}

Dessa forma, voltamos ao ponto de partida deste subitem. Corroborando a importância do compromisso de comparecimento à primeira reunião de mediação, e dando maior efetividade à cláusula de mediação, os autores da Lei de Mediação entenderam prudente penalizar a parte contratante que não honrou com a sua obrigação contratual. A penalidade imposta pela lei, é corolário dessa obrigatoriedade.

Conforme adiantado acima, a consequência da sanção em caso de cláusula compromissória completa ou "cheia", cabe inteiramente às partes, prevalecendo totalmente a autonomia da vontade.

Caso as partes não tenham convencionado a penalidade no contrato, recairá sobre à parte faltante a incumbência no pagamento de $50 \%$ das custas e honorários caso seja a parte vencedora em processo judicial ou procedimento arbitral posterior, conforme a letra do $\S 2^{\circ}$, inciso IV do art. 22 da Lei.

Essa penalidade altera a distribuição das verbas prevista no Código de Processo Civil, segundo a qual apenas a parte vencida é responsável pelo pagamento de custas e honorários advocatícios ${ }^{77}$, e pode significar um prejuízo enorme à parte penalizada.

A título de exemplo, caso a parte convidada à reunião de mediação não compareça ao primeiro encontro devido a um acontecimento imprevisto, e venha a ser ré em processo judicial ou procedimento arbitral

\footnotetext{
${ }^{76}$ PANTOJA \& OLIVEIRA, In: PELAJO (Coord.), 2016, p. 314.

${ }^{77}$ KREIDEL, Mark \& BIAZI, João Pedro. O Novo Regime Jurídico da Cláusula de Mediação. Levy \& Salomão Advogados. São Paulo, 30 jul. 2016. Disponível em: <http://www.levysalomao.com.br/publicacoes/Boletim/novo-regime-juridico-da-clausula-demediacao $>$. Acesso em: 17 out. 2016.
} 
relativo a contrato milionário com valor da causa altíssimo, sagrando-se vencedora ao fim do processo, mesmo assim ela terá o ônus de desembolsar $50 \%$ das custas e honorários sucumbenciais.

Como se depreende, a controvérsia acerca da penalidade imposta pela lei gira em torno do percentual que deve ser despendido pela parte que se ausentou à primeira reunião de mediação. Dessa forma, cabe indagar se o dispositivo foge da razoabilidade, sendo a penalidade demasiadamente onerosa à parte ou não.

Nesse contexto, revela-se interessante estabelecer uma comparação entre a sanção imposta à parte faltante na primeira reunião de mediação pactuada em cláusula compromissória de mediação, e a penalidade imposta em caso de mediação judicial.

Como se sabe, o novo Código de Processo Civil trouxe a audiência de composição obrigatória. Assim, o réu não é mais intimado a contestar a demanda no procedimento comum, e sim a comparecer a uma audiência de conciliação ou de mediação que passa a ser compulsória.

Conforme prevê o art. 334. $§ 8^{\circ}$ do Código de Processo Civil:

O não comparecimento injustificado do autor ou do réu à audiência de conciliação (e mediação) é considerado ato atentatório à dignidade da justiça e será sancionado com multa de até dois por cento da vantagem econômica pretendida ou do valor da causa, revertida em favor da União ou do Estado.

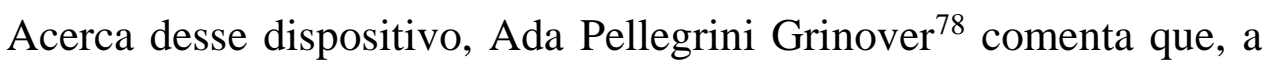
previsão de sanções para o não comparecimento injustificado do autor ou do réu à audiência de mediação/conciliação tem o escopo de incentivar a autocomposição, salientando que apenas a sua tentativa é obrigatória, e que a mesma depende exclusivamente da vontade das partes.

\footnotetext{
${ }^{78}$ GRINOVER, Ada Pellegrini. O minissistema brasileiro de Justiça consensual: compatibilidades e incompatibilidades. Publicações da Escola da AGU. v. 8. n. 1. jan./mar. 2016. Disponível em: 〈http://dirittoetutela.uniroma2.it/files/2013/03/Origens-e-evolu\%C3\%A7\%C3\%A3o.pdf〉. Acesso em: 20 out. 2016.
} 
Percebe-se, que o CPC classificou o não comparecimento à reunião na qual se pretende iniciar a mediação judicial, como uma afronta à ordem jurisdicional, impondo uma penalidade à parte que desrespeitar esse comando.

Assim, constata-se que em ambos os casos o legislador impõe uma penalidade à parte que não comparece à reunião de mediação, com o fim de estimular a mediação e encorajar as partes a tentarem mediar. $\mathrm{O}$ que se questiona não é a imposição de uma sanção, mas sim o quão gravosa esta sanção deve ser.

Note-se, que embora o CPC estabeleça uma penalidade à parte que violou este dispositivo, imputando-lhe multa de até $2 \%$ do proveito econômico ou valor da causa, esta é consideravelmente inferior à penalidade cominada pela Lei de Mediação. Nesse cenário, vale questionar a proporcionalidade da sanção imposta no art. $22, \S 2^{\circ}$, inciso IV da Lei ${ }^{\circ}$ 13.140 de 2015, bem como o critério utilizado pelo legislador para estabelecer essa penalidade. 


\title{
CAPÍTULO 4 - EFEITO SUSPENSIVO DA CLÁUSULA COMPROMISSÓRIA DE MEDIAÇÃO
}

Merece destaque neste estudo, o art. 23 da Lei $\mathrm{n}^{\circ} 13.140$ que dispõe sobre a possibilidade de incluir na cláusula compromissória de mediação pacto de não litigância até o escoamento de determinado prazo ou condição estipulada pelas partes, sob pena de suspensão da ação ou procedimento arbitral em curso:

\begin{abstract}
Art. 23. Se, em previsão contratual de cláusula de mediação, as partes se comprometerem a não iniciar procedimento arbitral ou processo judicial durante certo prazo ou até o implemento de determinada condição, o árbitro ou o juiz suspenderá o curso da arbitragem ou da ação pelo prazo previamente acordado ou até o implemento dessa condição.
\end{abstract}

Parágrafo único. O disposto no caput não se aplica às medidas de urgência em que o acesso ao Poder Judiciário seja necessário para evitar o perecimento de direito.

Como bem pontuam Hale, Pinho e $\mathrm{Cabral}^{79}$, "a princípio a existência da cláusula não impede o prosseguimento judicial ou arbitral, a não ser que as partes expressamente o convencionem".

Nesse contexto, ao redigirem a cláusula os contratantes podem convencionar expressamente que se absterão de início a uma lide no judiciário ou em juízo arbitral até o implemento de certa condição ou prazo. Suponhamos que em um contrato firmado entre as empresas "X" e "Y", haja cláusula dizendo que as partes não poderão interpor ação judicial para discutir o contrato, salvo se tiverem tentado a mediação pelo prazo máximo de 6 meses.

Assim, caso seja iniciada demanda judicial ou procedimento arbitral, em manifesta violação ao ajuste das partes, o juiz ou árbitro em exercício

\footnotetext{
${ }^{79}$ HALE, 2015, p. 66-67.
} 
deverá suspender o andamento da lide até que seja concretizada a condição estabelecida entre as partes, ou até escoado o prazo.

Da mesma maneira, se as partes se comprometerem a não iniciar procedimento arbitral ou processo judicial até que cumprida a fase prévia de mediação, o árbitro ou juiz deverá suspender o seu curso até que as partes compareçam à reunião de mediação ou até que se considere rejeitado o convite feito de uma parte a outra a participar do procedimento.

Ressalte-se, que o efeito suspensivo na hipótese de desrespeito ao pacto foi excepcionado em casos de tutela de urgência, conforme o parágrafo único do art. 23, haja vista a necessidade de se evitar o perecimento do direito nessas hipóteses.

Vale destacar que a Lei não definiu um prazo para o cumprimento da condição estipulada, limitando-se a dispor genericamente que as partes podem estipular na cláusula de mediação que se comprometerão a não iniciar procedimento arbitral ou processo judicial "durante certo prazo ou até o implemento de determinada condição".

A respeito do dispositivo, Alexandre Assed e Larissa Davidovich ${ }^{80}$ expõe que, trata-se de interessante mecanismo de incentivo à mediação no qual:

As partes poderão preparar o terreno, tornando mais fértil a busca por uma solução consensual para eventuais conflitos que venham a surgir durante a execução do contrato. Utilizando-se do fator tempo ou de algum elemento da relação contratual, fomenta-se a autocomposição.

Outrossim, Ângelo Volpi Neto ${ }^{81}$ dá conotação positiva à norma, ao dizer que a norma serve como mais uma demonstração de prestígio à mediação.

\footnotetext{
${ }^{80}$ ASSED \& DAVIDOVICH In: PELAJO, et al.. (Coord.), 2016, p. 346.

${ }^{81}$ NETO, Angelo Volpi. Cláusula Compromissória de Mediação em Contratos. Recivil. Disponível em: <http://www.recivil.com.br/noticias/noticias/view/artigo-clausula-de-mediacaopor-angelo-volpi-neto.html>. Acesso em: 23 out. 2016.
} 
Por outro lado, Humberto Pinho ${ }^{82}$ suscita a omissão na Lei acerca do prazo para o implemento de condição. Nesse sentido, ele expõe que a redação da norma denota vício de inconstitucionalidade, eis que diante de condição inexequível, os contratantes terão as vias judiciais e arbitrais terminantemente obstruídas, em afronta ao princípio constitucional da inafastabilidade judicial:

(...) o texto, tal como redigido, padece de inconstitucionalidade, pois o estabelecimento de eventual condição, infactível, pode inviabilizar permanentemente $\mathrm{o}$ acesso à jurisdição e a isso se opõe o princípio da inafastabilidade judicial, consagrado no art. $5^{\circ}, \mathrm{XXXV}$, da CF.

Dessa forma, a cláusula seria inexequível ou abusiva, pois as pessoas poderiam usá-la de forma imprópria na esfera privada.

Haja vista a possibilidade de as partes estabelecerem condições de execução inviáveis, o autor propõe como alternativa, que a Lei imponha aos contratantes ou ao juiz (ou árbitro) da lide em curso, a fixação de um limite temporal para o cumprimento da condição estipulada:

A melhor alternativa, certamente, teria sido a submissão do implemento de determinada condição a um limite temporal fixado na própria norma ou pelo juiz. Jamais, se poderia deixar "em aberto" o implemento da condição, como condição para o prosseguimento da ação.

Insta notar, que todas as intervenções de mediação em processos judiciais no exterior submetem-se, necessariamente, a um limite temporal. $\mathrm{Na}$ Inglaterra, v. g., "um tribunal inglês pode ordenar que o processo seja suspenso por um mês, enquanto as partes tentam um acordo através de um ADR ou outra modalidade de negociação" ${ }^{\text {. }}$.

\footnotetext{
${ }^{82}$ PINHO, 2014, Acesso em: 03 mai. 2016.

${ }^{83}$ PINHO, Humberto Dalla Bernardina de. A Nova Lei de Mediação Brasileira Comentários ao Projeto de Lei n ${ }^{\circ} 7169 / 14$. Revista Eletrônica de Direito Processual. Ano 8. Volume Especial. Rio de Janeiro, 2014. Disponível em: <https://www.academia.edu/8676991/Revista_Eletrônica_de_Direito_Processual_REDP_A_NO VA_LEI_DE_MEDIAÇÃO_BRASILEIRA_COMENTÁRIOS_AO_PROJETO_DE_LEI_N_7.16 914>. Acesso em: 03 mai. 2016 apud ANDREWS, Neil. Mediaçãa e arbitragem na Inglaterra. São Paulo: Revista dos Tribunais, 2012. p. 289.
} 
Sobre os efeitos endoprocessuais da mediação extrajudicial, em 2011 tramitava na Itália o Projeto Folena (n. 4567/C), no qual o juiz pode suspender o processo, mesmo ultimada a audiência de instrução e remeter a causa a um conciliador (mediador), que tentará o acordo. Mas, a suspensão do processo judicial e o fim do processo de mediação não podem exceder a noventa dias ${ }^{84}$. O mesmo se dá nos Estados Unidos, v. g., multidoor courthouse, sempre com limitação temporal para a conclusão do processo de mediação ${ }^{85}$.

Veja-se que dessa forma, dá-se tempo para as partes buscarem a solução consensual do conflito, garantindo-se na hipótese de condição irrealizável, a apreciação da questão no poder judiciário, em conformidade com o princípio constitucional da inafastabilidade da jurisdição.

Logo, merece atenção a sugestão de Pinho, de forma que a redação do dispositivo ganhe acréscimo, a fim de:

Submeter o implemento de determinada condição a um limite temporal fixado na própria norma ou pelo juiz, sem deixar "em aberto" o implemento da condição, como condição para o ajuizamento ou o prosseguimento da ação ${ }^{86}$.

\footnotetext{
${ }^{84}$ PINHO, Humberto Dalla Bernardina de. (org.). A Nova Lei de Mediação Brasileira Comentários ao Projeto de Lei n ${ }^{\circ}$ 7169/14. Revista Eletrônica de Direito Processual. Ano 8. Volume Especial. Rio de Janeiro, 2014. Disponível em: <https://www.academia.edu/8676991/Revista_Eletrônica_de_Direito_Processual_REDP_A_NO VA_LEI_DE_MEDIAÇÃO_BRASILEIRA_COMENTÁRIOS_AO_PROJETO_DE_LEI_N_7.16 914>. Acesso em: 03 mai. 2016 apud CHIARLONI, Sergio. I meccanismi conciliativi. São Paulo: Revista dos Tribunais, 2012. p. 95.

${ }^{85}$ Ibid., p. 264.

${ }^{86}$ PINHO, 2014, Acesso em: 03 mai. 2016.
} 


\section{CAPÍTULO 5 - QUESTÃO CONTROVERSA DA INCLUSÃO DE CLÁUSULA COMPROMISSÓRIA DE MEDIAÇÃO EM CONTRATOS DE ADESÃO}

Interessante questão que merece ser abordada neste estudo gira em torno da aplicabilidade da cláusula compromissória de mediação em contratos de adesão. Nessa esteira, vale analisar a natureza e peculiaridades desta espécie contratual.

O contrato de adesão, por definição é negócio jurídico bilateral ou plurilateral, no qual apenas uma das partes - proponente ou estipulante decide previamente quais as cláusulas serão efetivamente inseridas no contrato, de modo que, a outra parte - aderente -, apenas anui ou não, com aquilo já estabelecido, ficando esta impedida de modificar substancialmente as condições do contrato. A título de exemplo, contratos de adesão podem envolver o fornecimento de água, energia elétrica, transporte urbano, dentre outros. Assim, basta ao aderente, por óbvio o eixo mais fraco da relação jurídica, aderir às cláusulas pré-estabelecidas unilateralmente pelo proponente.

Ressalte-se que o Código Civil protegeu a figura do aderente e reconheceu a sua fragilidade em dois dispositivos:

Art. 423. Quando houver no contrato de adesão, cláusulas ambíguas ou contraditórias, dever-se-á adotar a interpretação mais favorável ao aderente.

Art. 424. Nos contratos de adesão, são nulas as cláusulas que estipulem a renúncia antecipada do aderente a direito resultante da natureza do negócio.

Ainda acerca desta espécie contratual, Orlando Gomes ${ }^{87}$ elucida que “(...) no contrato de adesão uma das partes tem que aceitar, em bloco, as

${ }^{87}$ GOMES, Orlando. Contratos. $18^{\circ}$ ed. Atualizada e anotada por Humberto Theodoro Júnior. Rio de Janeiro: Forense, 1998. p. 109-119. 
cláusulas estabelecidas pela outra, aderindo uma situação contratual que encontra definida em todos os seus termos".

É nítido, portanto, o risco intrínseco do aderente à essa espécie contratual, eis que o proponente lhe impõe uma série de cláusulas que devem ser aquiescidas integralmente, restringindo em muito o poder do aderente de manifestar a sua vontade.

Considerando a letra da Lei e a natureza desse tipo de contrato, indaga-se: caberia a inclusão de cláusula compromissória de mediação em contratos de adesão? Vejamos a melhor maneira de responder a esse questionamento.

Conforme previamente abordado neste estudo e determinado nos $\S 1^{\circ}$ e $2^{\circ}$ do art. $2^{\circ}$ da Lei, na hipótese de previsão contratual de Mediação as partes são obrigadas a comparecer à primeira reunião, não sendo, todavia, compelidas a permanecer em procedimento de Mediação.

Tendo em vista a omissão na redação final do dispositivo acerca dos contratos de adesão, não é possível responder à indagação posta de forma objetiva. Cabe então uma reflexão do tema de forma a esclarecer qual seria a interpretação mais adequada da norma e o que foi pretendido pelo legislador.

O instituto da mediação é marcado pela voluntariedade e adesão espontânea das partes. Isso é dizer, trata-se de método de solução consensual facultativa, que não é imposto por uma parte e assentido por outra, mas sim eleito de comum acordo por todos. Como observam Humberto Pinho e Michele Paumgartten ${ }^{88}$, a mediação obrigatória não se coaduna com a própria essência do instituto.

\footnotetext{
${ }^{88}$ PINHO, Humberto Dalla Bernardina de \& PAUMGARTTEN, Michele Pedrosa. Mediação Obrigatória: Um oximoro jurídico e mero placebo para a crise do acesso à justiça. In: $X X I$ ENCONTRO NACIONAL CONPEDI. Uberlândia, 2012. p. 414-437. Disponível em: <http://www.humbertodalla.pro.br/arquivos/mediacao_obrigatoria _conpedi.pdf>. Acesso em: 01 mai. 2014. p. 418.
} 
Em um primeiro momento, percebe-se que a natureza do contrato de adesão colide com a da mediação, visto que essa espécie contratual não dá margem à negociação, diferentemente do que ocorre na mediação, instituto marcado pela negociação das partes auxiliadas por um terceiro imparcial.

A respeito dessa questão, Alexandre Assed e Larissa Davidovich ${ }^{89}$ aclaram que o legislador foi alvo de críticas por não ter excepcionado da Lei os contratos de adesão, especialmente os contratos relativos a direitos do consumidor.

Os autores explanam que:

(...) para alguns, a ausência de previsão dessa exceção, leva a crer que a cláusula compromissória objetivaria de maneira transversa, criar uma condição de procedibilidade para ações judiciais, fazendo crer que nos contratos em que houvesse essa estipulação expressa, tornar-se-ia imprescindível que as partes se submetessem inicialmente à Mediação, deixando de considerar a relação desbalanceada, em razão da vulnerabilidade técnica, operacional e econômica dos consumidores.

Nesse contexto, os aderentes estariam obrigados a participar de uma primeira reunião de mediação imposta por cláusula de mediação préestabelecida unilateralmente pelo estipulante, sem direito de oposição à essa cláusula, visto que em contratos de adesão o aderente não pode discutir nem modificar os termos do contrato de forma substancial.

Note-se que essa omissão do legislador importaria em um desvirtuamento do instituto da mediação em detrimento do contratante vulnerável, na medida em que a imposição unilateral da mediação pelo proponente, impediria que o aderente iniciasse processo judicial diretamente, tornando a cláusula abusiva.

Sendo assim, os autores entendem que esse artigo acaba permitindo a inclusão de cláusula de mediação em contratos de adesão, e ponderam que o dispositivo "deveria, portanto, ter excepcionado expressamente os contratos

\footnotetext{
${ }^{89}$ ASSED \& DAVIDOVICH In: PELAJO, et al.. (Coord.), 2016, p. 345.
} 
de adesão em que a manifestação de vontade de uma das partes encontra-se mitigada".

Vale ratificar neste estudo, que embora o legislador não tenha feito nenhuma ressalva na Lei acerca dos contratos de adesão, o tema foi amplamente debatido nas iniciativas legislativas que culminaram na sua consolidação, o que leva a crer que a omissão a esse respeito, foi totalmente consciente. Como se verá, o legislador cogitou incluir a exceção, mas suprimiu essa ressalva na redação final do texto legislativo. Para a melhor compreensão do leitor, faz-se mister analisar as proposições legislativas que resultaram na Lei de Mediação.

O Projeto de Lei $\mathrm{n}^{\mathrm{o}} 517$ de 2011, de autoria do Senador Ricardo Ferraço, previa em seu art. $15, \S 2^{\text {o90 }}$ a seguinte ressalva:

Art. 15. A cláusula compromissória é a convenção através da qual as partes em um contrato comprometem-se a submeter à mediação os litígios que possam vir a surgir, relativamente a tal negócio jurídico.

§ 1o A cláusula compromissória deve ser estipulada por escrito, podendo estar inserta no próprio contrato ou em documento apartado que a ele se refira.

§ 2o Nos contratos de adesão, a cláusula compromissória só terá eficácia se o aderente tomar a iniciativa de instituir a mediacão ou concordar, expressamente, com a sua instituição, desde que por escrito em documento anexo ou em negrito, com a assinatura ou visto especialmente para essa cláusula

Como se pode notar, o primeiro projeto de lei que propôs a regulamentação da mediação judicial e extrajudicial, sujeitou a eficácia da cláusula compromissória de mediação em contratos de adesão à: (i) iniciativa de instituição da mediação pelo aderente; ou (ii) concordância expressa do aderente por escrito em documento anexo ou em negrito com a assinatura ou visto especialmente para essa cláusula.

\footnotetext{
90 BRASIL. Senado Federal. Disponível em: <http://legis.senado.leg.br/mateweb/arquivos/matepdf/95105.pdf >. Acesso em: 15 out. 2016.
} 
Dito de outro modo, o legislador entendeu à época que apenas a manifestação expressa de vontade do aderente, no sentido de instituir a mediação, teria o condão de validar a cláusula compromissória de mediação nos contratos de adesão, balanceando a relação e conferindo à parte vulnerável maior poder na tomada de decisão.

Assim, louvável o escopo contido no projeto de Lei que deu origem à Lei $\mathrm{n}^{\circ} 13.140$, pois o contrato de adesão contaria com previsão específica definida pelo aderente, haja vista a presunção de desigualdade existente entre o proponente e o aderente, especialmente em razão da vulnerabilidade deste último.

Em 2013, foram apensados ao PLS 517, mais duas iniciativas legislativas: o PLS $\mathrm{n}^{\circ}$ 405/2013, nascido do trabalho realizado por Comissão instituída pelo Senado e presidida pelo Ministro Luis Felipe Salomão, do Superior Tribunal de Justiça, e o PLS no 434/2013, fruto de Comissão instituída pelo CNJ e pelo Ministério da Justiça, presidida pelos Ministros Nancy Andrighi e Marco Buzzi, ambos do STJ, e pelo Secretário da Reforma do Judiciário do Ministério da Justiça, Flavio Croce Caetano ${ }^{91}$.

Em novembro de 2013 foram marcadas audiências públicas com o fim de discutir os três projetos e amadurecer questões controvertidas pendentes. O Relator da matéria no Senado, Senador Vital do Rego, apresentou um Substitutivo ao PLS 517/11 com o fito de reunir o que há de melhor nas três iniciativas ${ }^{92}$.

Na Câmara, o texto passou a tramitar como Substitutivo da Câmara dos Deputados PL n ${ }^{\circ}$ 7.169, de 2014, com relatoria do Deputado Sérgio Zveiter. Ao justificar a necessidade do Substitutivo ao Projeto de Lei 7.169, o Relator ressaltou os principais pontos que necessitavam de ajustes, abordando dentre eles, a questão controversa da cláusula compromissória de mediação em contratos de adesão. Acerca do tema, o Deputado entendeu

\footnotetext{
${ }^{91}$ HALE, 2016, p. 11.

92 PINHO, 2014, Acesso em: 03 mai. 2016.
} 
pela inaplicabilidade integral desta previsão contratual em contratos de $\operatorname{adesão~}^{93}$ :

(...) Ressalta-se que, com o objetivo de se evitar abusos contratuais, aos contratos de adesão, não se aplica a clausula de mediação.

Dessa maneira, o deputado propôs em seu relatório, que o $§ 3$ do art. $2^{o}$ fizesse menção expressa à impossibilidade de inclusão da referida cláusula, na hipótese de contrato de adesão:

Art. $2^{\circ}$ A mediação será orientada pelos seguintes princípios:

(...)

$\S 1^{\circ}$ Ninguém será obrigado a submeter-se a procedimento de mediação.

$\S 2^{\mathrm{a}} \mathrm{Na}$ hipótese de existir previsão contratual de clausula de mediação, as partes deverão comparecer à primeira reunião de mediação.

\section{§3 Não se aplica a cláusula de mediacão aos contratos de adesão.}

Vê-se que na segunda alteração do texto legislativo proibir-se-ia completamente a inserção da cláusula de mediação nos contratos de adesão a fim de evitar abusos contratuais. Note-se, que o legislador foi aqui mais inflexível, ao suprimir o direito - antes havido - do aderente de eleger a cláusula, e deixando de especificar suas hipóteses de cabimento e limitações. Do ponto de vista de Humberto Pinho ${ }^{94}$, a inovação proposta no relatório do Deputado Sérgio Zveiter, acerca da inaplicabilidade de cláusula compromissória de mediação em contratos de adesão é bem-vinda, pois cria mecanismo que se aproxima ao da cláusula arbitral. Todavia, o autor relativiza essa afirmação, e conclui dizendo que:

\footnotetext{
${ }^{93}$ BRASIL. Câmara dos Deputados. Disponível em: <http://www.camara.gov.br/proposicoesWeb/prop_mostrarintegra?codteor $=1260500 \&$ filename $=$ T ramitacao-PL+7169/2014>. Acesso em: 25 set. 2016.

${ }^{94}$ PINHO, 2014, Acesso em: 03 mai. 2016.
} 
Deve ser mantida a simetria com os dispositivos do Projeto de Lei $\mathrm{n}^{\circ}$ 7108/14 que culminou na Lei $\mathrm{n}^{\circ} 13.129$ de 2015 - ${ }^{95}$ que trata da arbitragem, sobretudo quanto às restrições à cláusula compromissória ${ }^{96}$.

Assim, na concepção de Pinho, o ajuste proposto pelo Deputado Sérgio Zveiter mostra-se demasiadamente radical, eis que retira do aderente a prerrogativa de inclusão da cláusula compromissória de mediação em contrato de adesão, caso este queira fazê-lo.

Para o autor:

Seria necessário especificar um pouco mais o cabimento e as restrições à cláusula de mediação, sobretudo naquelas hipóteses nas quais há direitos indisponíveis. É algo que se não for amadurecido neste momento, terá que ser decidido, posteriormente, pela jurisprudência.

Feitas essas considerações, cumpre destacar que houve nova remessa do Substitutivo ao PL no 7.169 ao Senado em 2015, consolidando-se assim o Substitutivo da Câmara no 9/2015 ao Projeto de Lei do Senado n ${ }^{\circ}$ 517, de 2011 ( $n^{\circ}$ 7.169/2014, na Câmara dos Deputados), aprovado em 2 de junho de 2015. Em 29 de junho foi, finalmente, publicada no Diário Oficial da União a Lei n ${ }^{\circ} 13.140 / 2015$.

Como se sabe, a redação final da Lei de Mediação não incorporou a exceção proposta pelo Senador Zveiter, silenciando-se inteiramente acerca da possibilidade de inclusão de cláusula compromissória de mediação em contratos de adesão.

\footnotetext{
${ }^{95}$ O Projeto de Lei 7108/14 culminou na Lei 13.129, que alterou os dispositivos da Lei de Arbitragem (Lei 9.307 de 1996).

BRASIL. Câmara dos Deputados. Disponível em:

$<$ http://www.camara.gov.br/proposicoesWeb/prop_mostrarintegra?codteor=1225529\&filename=P L+7108/2014>. Acesso em: 25 set. 2016.

${ }^{96}$ Vale destacar, que à ocasião, desta afirmação, o referido Projeto de Lei 7108/14, que alterou a Lei de Arbitragem (Lei 9.307 de 1996) ainda trafegava na Câmara dos Deputados e dispunha que nos contratos de adesão, a cláusula compromissória de arbitragem somente valeria se fosse redigida em negrito ou em documento anexo:

Art. $4^{\circ}$ A cláusula compromissória é a convenção através da qual as partes em um contrato comprometem-se a submeter à arbitragem os litígios que possam vir a surgir, relativamente a tal contrato.

(...)

$\$ 2^{\circ}$ Nos contratos de adesão, a cláusula compromissória só terá eficácia se for redigida em negrito ou em documento apartado.
} 
Embora o legislador não tenha excepcionado da Lei de Mediação os contratos de adesão, este o fez na Lei de Arbitragem, com a imposição de uma série de restrições conforme se infere da redação original do art. $4^{\circ} \S 2^{\circ}$ da Lei de Arbitragem, que restou inalterado pela Lei no 13.129 de 2015:

Art. $4^{\circ}$ A cláusula compromissória é a convenção através da qual as partes em um contrato comprometem-se a submeter à arbitragem os litígios que possam vir a surgir, relativamente a tal contrato.

$\$ 2^{\circ}$ Nos contratos de adesão, a cláusula compromissória só terá eficácia se o aderente tomar a iniciativa de instituir a arbitragem ou concordar, expressamente, com a sua instituição, desde que por escrito em documento anexo ou em negrito, com a assinatura ou visto especialmente para essa cláusula.

Percebe-se que o dispositivo vigente da Lei de Arbitragem é mais favorável ao contratante economicamente mais fraco, eis que impõe maior rigor formal na estipulação de cláusula compromissória de arbitragem, e concomitantemente evita que a parte mais forte imponha ao aderente a adoção da arbitragem como forma de solução de eventual conflito. Além disso, destaca-se que sua redação é idêntica ao primeiro projeto de lei que propôs a regulamentação da mediação judicial e extrajudicial

Convém ressaltar, que esse dispositivo, tem o mesmo alcance da sugestão original de Humberto Pinho para a Lei de Mediação, visto que o autor entende que deve haver a possibilidade de inclusão de cláusula de mediação em contratos de adesão, contanto que a Lei melhor especifique o seu cabimento e as suas restrições, tal como ocorre na arbitragem.

Interessante notar também, que a norma contida no $\S 2$, art. $4^{\circ}$ da Lei de Arbitragem não se limita aos contratos de adesão genéricos, tendo em vista que o dispositivo não faz nenhum tipo de restrição ou exceção. Assim, quando dispõe sobre contratos de adesão, certamente abrange as relações de consumo, desde que sejam respeitados além dos requisitos definidos em lei, os direitos e garantias previstos no CDC. 
Dessa maneira, importante destacar a relevância desta norma para os contratos de adesão relativos às relações de consumo, considerando o desequilíbrio inerente à essa relação. $\mathrm{O}$ contrato de adesão nas relações de consumo, é aquele redigido inteiramente pelo fornecedor de bens e serviços, sem que o consumidor possa discutir ou alterar seus termos de forma substancial, consoante o art. 54 do Código de Defesa do Consumidor

Nesse sentido, Cláudia Lima Marques ${ }^{97}$, entende que:

Limita-se o consumidor a aceitar em bloco (muitas vezes sem sequer ler completamente) as cláusulas, que foram unilateral e uniformemente préelaboradas pela empresa, assumindo, assim, um papel de simples aderente à vontade manifestada pela empresa no instrumento contratual massificado.

A única exigência que o CDC põe ao fornecedor, é uma redação clara com caracteres ostensivos e legíveis ${ }^{98}$, além de destaque às cláusulas limitativas de direitos ${ }^{99}$.

Diante da flagrante omissão na Lei de Mediação, revela-se interessante considerar a aplicação por analogia do art. $4^{\circ} \S 2^{\circ}$ da Lei de Arbitragem à Lei de Mediação, suprindo-se a lacuna legislativa em conformidade com o art. $4^{\circ}$ da Lei de Introdução às Normas do Direito Brasileiro $^{100}$.

Desse modo, é pertinente, verificar a interpretação adotada nos Tribunais acerca dos contratos de adesão - aplicável tanto aos contratos genéricos, como os que aludem às relações de consumo - no âmbito da Lei de Arbitragem.

\footnotetext{
${ }^{97}$ MARQUES, Claudia Lima. Contratos no Código de Defesa do Consumidor. Revista dos Tribunais, 1992. p. 31.

${ }^{98}$ Art. 54 (...)

$\S 3^{\circ}$ Os contratos de adesão escritos serão redigidos em termos claros e com caracteres ostensivos e legíveis, cujo tamanho da fonte não será inferior ao corpo doze, de modo a facilitar sua compreensão pelo consumidor.

${ }^{99}$ Art. 54 (...)

$\S 4^{\circ}$ As cláusulas que implicarem limitação de direito do consumidor deverão ser redigidas com destaque, permitindo sua imediata e fácil compreensão.

${ }^{100}$ Art. 4o - Quando a lei for omissa, o juiz decidirá o caso de acordo com a analogia, os costumes e os princípios gerais de direito.
} 
A $4^{\mathrm{a}}$ Turma do Superior Tribunal de Justiça julgou em $1^{\mathrm{o}}$ de março de 2016, o Recurso Especial $\mathrm{n}^{\mathrm{o}}$ 1.189.050/SP ${ }^{101}$, acerca da validade de cláusula compromissória de arbitragem inserida em contrato de adesão, em relação de consumo de compra e venda de imóvel. No caso concreto, o órgão colegiado seguiu por unanimidade o voto do relator, Ministro Luis Felipe Salomão.

A cláusula arbitral foi considerada válida em $1^{\mathrm{a}}$ e $2^{\mathrm{a}}$ instâncias, tendo em vista que foi livremente aquiescida por ambas as partes à época da aquisição do imóvel na planta direto com a construtora ${ }^{102}$. Irresignado com a validação da cláusula, o consumidor então recorreu ao STJ.

Conquanto a Corte tem prestigiado a arbitragem como mecanismo de solução de conflitos, o Ministro Relator assinalou que quando o tema é a convenção de arbitragem instituída em contratos de adesão, a jurisprudência do STJ "vem sendo um pouco mais reticente".

Desse modo, o magistrado registrou que o Código de Defesa do Consumidor não é contrário ao uso da arbitragem nos conflitos de consumo, porém ressalva a forma de imposição da cláusula compromissória, que não poderá ocorrer de forma impositiva.

A pertinência do referido diploma legal justifica a sua transcrição a seguir:

Art. 51. São nulas de pleno direito, entre outras, as cláusulas contratuais relativas ao fornecimento de produtos e serviços que:

VII - determinem a utilização compulsória de arbitragem.

O ministro ressaltou que:

\footnotetext{
101 Íntegra do Recurso Especial $n^{\circ} 1.189 .050 / S P$. Disponível em: <http://www.adambrasil.com/wp-content/uploads/2016/03/resp1189050sp_stj.pdf>. Acesso em: 20 out. 2016.

${ }^{102}$ Cláusula arbitral em contrato de adesão é válida se consumidor tomar iniciativa ou ratificá-la. Migalhas. Disponível em: <http://www.migalhas.com.br/Quentes/17,MI235005,101048Clausula+arbitral+em+contrato+de+adesao+e+valida+se+consumidor+tomar $>$. Acesso em: 20 out. 2016.
} 
O $\S 2^{\circ}$ do art. $4^{\circ}$ da Lei $n^{\circ}$ 9.307/96 não se limita aos contratos de adesão genéricos, haja vista que, como visto, a norma não fez nenhum tipo de restrição ou exceção; assim, quando fala em contratos de adesão, por óbvio, parece que está também a englobar as relações de consumo, desde que sejam respeitados, além dos requisitos definidos em lei, os direitos e garantias previstos no CDC.

\section{Ainda segundo o ministro Luis Felipe Salomão:}

Só terá eficácia a cláusula compromissória já prevista em contrato de adesão se o consumidor vier a tomar a iniciativa do procedimento arbitral, ou se vier a ratificar posteriormente a sua instituição, no momento do litígio em concreto.

Seguindo essa linha de raciocínio, o ministro conclui que:

Não haverá nulidade da cláusula se o fornecedor demonstrar que não impôs a utilização compulsória da arbitragem, ou também pela ausência de vulnerabilidade que justifique a proteção do consumidor.

O magistrado reforçou que a instauração da arbitragem vincula o fornecedor, mas a recíproca não é verdadeira.

Com isso, evita-se qualquer forma de abuso, na medida em o consumidor detém, caso desejar, o poder de libertar-se da via arbitral para solucionar eventual lide com o prestador de serviços ou fornecedor. É que a recusa do consumidor não exige qualquer motivação. Propondo ele ação no Judiciário, haverá negativa (ou renúncia) tácita da cláusula compromissória.

Dessa maneira, assentou-se a possibilidade da inclusão de cláusula arbitral em contrato de adesão de consumo quando não houver vulnerabilidade do consumidor, ou imposição pelo fornecedor, bem como quando a iniciativa da instauração da arbitragem for do consumidor ou, no caso de iniciativa do fornecedor, o consumidor venha a concordar ou ratificar expressamente a instituição, afastada qualquer possibilidade de abuso.

Cumpre destacar que no caso em tela, o contrato de adesão previa a cláusula compromissória arbitral, porém, considerando que a mera propositura da ação pelo consumidor é hábil para demonstrar o seu 
desinteresse na adoção da arbitragem, o ministro Salomão reconheceu a nulidade da cláusula.

Assim, aplicando-se analogicamente o art. $4^{\circ} \S 2^{\circ}$ da Lei de Arbitragem no âmbito da mediação, entende-se que seria viável a inclusão de cláusula compromissória de mediação em contrato de adesão - seja este genérico ou de consumo - quando a iniciativa da instauração da mediação ocorrer pelo aderente (ou consumidor) ou, no caso de iniciativa do proponente (ou fornecedor), venha a concordar ou ratificar expressamente a sua instituição.

Acrescente-se que em contratos de adesão relacionados às relações de consumo, caso não ocorra a imposição da cláusula pelo fornecedor ou a vulnerabilidade do consumidor, é evidente que inexiste qualquer possibilidade de abuso.

Claudia Frankel Grosman e Sandra Regina Garcia Olivan Bayer ${ }^{103}$ expõe que:

(...) por tratar-se de relação com parte que não está desenvolvendo atividade de natureza comercial, a legislação prevê uma série de medidas protetivas ao consumidor em relação ao fornecedor, mesmo que esse seja uma pessoa jurídica. Nesse caso, a cláusula compulsória (e não compromissória) de arbitragem é considerada abusiva (Art. 51, VII, do Código de Defesa do Consumidor). Assim sendo, a arbitragem pode estar prevista no contrato, mas como uma possibilidade pela qual o consumidor pode ou não optar, quando do surgimento da controvérsia.

Da mesma maneira, as autoras complementam o raciocínio aduzindo que "uma cláusula que obrigasse a mediação seria considerada leonina, mas isso não obsta que as empresas optem pela mediação”.

Assim, concorda-se que a previsão contratual de mediação só terá eficácia se houver iniciativa da parte vulnerável de instituir a mediação, ou concordância expressa com a sua instituição, sendo vedado que o fornecedor imponha ao consumidor a mediação de forma compulsória.

${ }^{103}$ GROSMAN, 2016, p. 388. 
Nesse contexto, vale a reflexão acerca da aplicação do dispositivo da Lei de Arbitragem no âmbito da Mediação, eis que a norma revela comprometimento com a autonomia da vontade das partes, ao mesmo tempo em que blinda o aderente ou consumidor, afastando qualquer possibilidade de abuso nos contratos de adesão, sejam eles genéricos ou de consumo. Trata-se de questão que se não for ponderada neste momento, terá que ser decidida, posteriormente, pela jurisprudência. 


\section{CONCLUSÃO}

Frente ao exposto neste estudo, a eleição da mediação para a solução de controvérsias contratuais merece o destaque que vem efetivamente recebendo dos estudiosos do Direito, assim como dos entusiastas da mediação em tão pouco tempo do marco legal da mediação.

A ênfase se justifica na medida em que a previsão contratual de cláusula compromissória de mediação oferece enormes benefícios no tratamento dos aspectos objetivos e subjetivos intrínsecos aos negócios jurídicos, quais sejam, contratos empresariais, comerciais, de seguro, relativos às empresas familiares, e até mesmo em recuperação judicial.

Deduz-se que essa cláusula, pautada inteiramente na autonomia da vontade das partes tem o condão de estimular os contratantes a tentarem resolver futuras desavenças por meio da mediação, e prevenir eventual desgaste posterior na busca de uma solução para o conflito. Ao invés de outorgarem o poder decisório acerca da disputa contratual, as partes assumem o protagonismo no procedimento da mediação, construindo juntas uma solução para o conflito com o auxílio de um terceiro imparcial.

Como bem observa Tânia Almeida"104, "construir uma solução pautada na satisfação mútua não implica em ceder ao que o outro deseja, mas sim atuar de modo cooperativo, mantendo a assertividade em duplo sentido".

Há de se concluir pela enorme significância da mediação em conflitos contratuais, na medida em que as relações interpessoais são dinâmicas e em constante movimentação, o que permite dizer que as condições previstas em um contrato podem mudar a qualquer momento, considerando a mudança da realidade. Assim, deve se ter em mente que na produção do contrato, consideram-se certas expectativas dos contratantes,

104 ALMEIDA, Mediação e Conciliação: Duas práticas distintas, dois paradigmas diversos. Mediare. Acesso em: 21 abr. 2016. 
que muitas vezes acabam não sendo atendidas integralmente no decorrer da sua implementação, e que podem ser facilmente ajustadas pelas partes na inclusão de cláusula de mediação no contrato.

É de se constatar que o legislador conferiu ampla liberdade aos contratantes na redação do conteúdo deste termo. Respeitados os requisitos mínimos para a confecção da cláusula de mediação, as partes podem definir livremente o conteúdo desta, ou mesmo indicar regulamento de instituição de mediação que contenha critérios bem definidos. Na falta de previsão contratual completa, as partes devem aderir a determinadas condições impostas pela Lei, tais como prazo mínimo e máximo para a realização da primeira reunião de mediação, e penalidade em caso de não comparecimento à esta, dentre outras imposições.

Impende inferir que cláusula compromissória de mediação se mostra eficaz, na medida em que impõe à parte convidada à mediação a obrigatoriedade de comparecimento à primeira reunião. Além disso, acarreta em suspensão de processo judicial ou procedimento arbitral na hipótese de descumprimento de pacto facultativo de não litigância a ser respeitado durante certo prazo ou até o implemento de determinada condição.

No que tange a sua inclusão nos contratos de adesão, a omissão da Lei abre margem para o debate. Considerando tudo o que foi estudado para a elaboração desta tese, vale contemplar a aplicação do dispositivo da Lei de Arbitragem no âmbito da Mediação, eis que essa interpretação é capaz de afastar qualquer possibilidade de abuso nos contratos de adesão. Vale dizer que o debate ainda vai ocupar as pautas dos tribunais, levando a algum caminho que ainda não se pode ter certeza qual será.

Por fim, é necessário tecer um elogio ao nobre esforço do legislador, na tentativa de consagrar a mediação como método adequado para resolução de conflitos, abrindo-se espaço para o restabelecimento do 
diálogo e a continuidade das relações na esfera contratual por meio da cláusula compromissória de mediação. 


\section{REFERÊNCIAS BIBLIOGRÁFICAS}

ABDO, Helena Najjar. Abuso do processo. São Paulo: RT, 2007. In: TARTUCE, Fernanda. Mediação nos conflitos civis. $3^{\mathrm{a}}$ ed. ver. atual e ampl. Rio de Janeiro: Forense. São Paulo: Método, 2016.

ALBERTON, Genaceia da Silva. O Núcleo de Estudos no contexto da mediação no Rio Grande do Sul e as proposições legislativas na área da mediação. Disponível em: <http://www.ajuris.org.br/sitenovo/wpcontent/uploads/2014/12/o-nucleo-de-estudos-no-contexto-damediacao.pdf>. Acesso em: 18 set. 2016.

ALMEIDA, Diogo A. Rezende de \& PAIVA, Fernanda. Princípios da Mediação de Conflitos. In: Mediação de Conflitos para Iniciantes, Praticantes e Docentes. Parte I. Cap. 5, 2016.

ALMEIDA, Diogo A. Rezende de Almeida \& PANTOJA, Fernanda Medina. Áreas de atuação da Mediação de Conflitos. In: PELAJO, Samantha et al.. (Coord.). Mediação de Conflitos para Iniciantes, Praticantes e Docentes. Parte I. Cap. 6. Salvador: Ed. JusPodvim, 2016.

ALMEIDA, Diogo Assumpção Rezende de et al.. A Mediação no Novo Código de Processo Civil. VitalBook file. Rio de Janeiro: Editora Forense, 2015.

ALMEIDA, Tania \& GOMMA, Maurício. Um instrumento de pacificação social. Contratos de seguro: a importância da mediação na solução de conflitos. Disponível em:

$<$ http://docvirt.com/docreader.net/DocReader.aspx?bib=cader_segur\&pagfi s=304\&pesq $>$. Acesso em: 10 out. 2016.

ALMEIDA, Tania. Caixa de ferramentas em mediação: aportes práticos e teóricos. São Paulo: Dash, 2014.

ALMEIDA, Tânia. Mediação de Conflitos: Um meio de prevenção e resolução de controvérsias em sintonia com a atualidade. Mediare. Disponível em: <http://www.mediare.com.br/2016/03/01/mediacaode-conflitos-um-meio-de-prevencao-e-resolucao-de-controversias-emsintonia-com-a-atualidade/>. Acesso em: 21 abr. 2016.

ALMEIDA, Tania. Mediação e Conciliação: Dois paradigmas distintos, duas práticas diversas. In: CASTELLA, Paulo Borba \& SOUZA, Luciane 
Moessa de (Coords.). Mediação de Conflitos - Novo Paradigma de Acesso à Justiça. Belo Horizone: Ed. Fórum, 2009.

ALMEIDA, Tania. Mediação e Conciliação: Duas práticas distintas, dois paradigmas diversos. Mediare. Disponível em:

<http://www.mediare.com.br/2016/03/02/mediacao-e-conciliacao-doisparadigmas-distintos-duas-praticas-diversas/>. Acesso em: 21 abr. 2016.

ALMEIDA, Tânia. Mediação na virada do milênio. Mediare. 31 mai. 1999. Disponível em: <http://www.mediare.com.br/2016/02/29/mediacao-navirada-de-milenio/> . Acesso em: 19 abr. 2016.

ASSED, Alexandre Servino \& DAVIDOVICH, Larissa. A Nova Lei de Mediação: Comentários e Reflexões. In: PELAJO, Samantha et al.. (Coord.). Mediação de Conflitos para Iniciantes, Praticantes e Docentes. Parte I. Cap. 21. Salvador: Ed. JusPodvim, 2016.

AZEVEDO, André Gomma (org.) Manual de mediação judicial. $4^{\mathrm{a}}$ ed. Brasília/DF: Ministério da Justiça e Programa das Nações Unidas para o Desenvolvimento - PNUD, 2013. p. 172. Disponível em:

<http://www.cnj.jus.br/images/programas/conciliacao/manual_mediacao_ju dicial_4ed.pdf $>$. Acesso em: 17 set. 2016.

BASÍllO, Ana Tereza. A possibilidade de inclusão de cláusula de mediação em plano de Recuperação Judicial. Jota. 24 Set. 2016. Disponível em: <http://jota.info/possibilidade-de-inclusao-de-clausula-demediacao-em-plano-de-recuperacao-judicial>. Acesso em: 27 out. 2016.

BRASIL. Câmara dos Deputados. Disponível em:

<http://www.camara.gov.br/proposicoesWeb/prop_mostrarintegra?codteor= 1260500\&filename=Tramitacao-PL+7169/2014> . Acesso em: 25 set. 2016.

BRASIL. Câmara dos Deputados. Disponível em: <http://www.camara.gov.br/proposicoesWeb/prop_mostrarintegra?codteor= 1225529\&filename=PL+7108/2014> . Acesso em: 25 set. 2016.

BRASIL. Código de Processo Civil. Congresso Nacional. Lei no 5.869 de 11/01/1073. Brasília.

BRASIL. Lei n. 13.105 de 2015, Art. 173.

BRASIL. Lei no 13.140 de 26/06/2015. Brasília. 
BRASIL. Senado Federal. Disponível em: $\langle$ http://legis.senado.leg.br/mateweb/arquivos/mate-pdf/95105.pdf $>$. Acesso em: 15 out. 2016.

BRETT, Jeanne \& BARSNESS, Zoe. The Effectiveness of Mediation: An Independent Analysis of Cases Handled by Four Major Service Providers. 12 Neg. J 259, 1996. In: RISKIN, Leonard L. \& WESRBROOK, James E. Dispute Resolution and Lawyers. $2^{\mathrm{a}}$ ed. Saint Paul: West Group, 2004.

CALMON, Petronio. Fundamentos da mediação e conciliação. $3^{\mathrm{a}}$ ed. Brasilia, DF: Gazeta Jurídica, 2015.

CAPPELLETTI, Mauro. Libertà Individuale e Giustizia Sociale nel Processo Civile. Giustizia e Società. Milano: Edizioni di Comunità, 1977. p. 32 apud CUNHA, J. S. Fagundes. Da mediação e da arbitragem endoprocessual. In: Revista dos Juizados Especiais. v. 4. n. 14. São Paulo: Editora Fiuza, out./dez. 1999. Disponível em: <http://www.uepg.br/rj/a1v1at16.htm>. Acesso em: 23 mar. 2016.

Cláusula arbitral em contrato de adesão é válida se consumidor tomar iniciativa ou ratificá-la. Migalhas. Disponível em:

<http://www.migalhas.com.br/Quentes/17,MI235005,101048-

Clausula+arbitral+em+contrato+de+adesao+e+valida+se+consumidor+tom ar>. Acesso em: 20 out. 2016.

CUNHA, Leonardo Carneiro da. Notas sobre ADR, confidencialidade em face do julgador e prova inadmissível. Disponível em:

$<\mathrm{http}$ ://www.leonardocarneirodacunha.com.br/opiniao/opiniao-26-notassobre-adrconfidencialidade-em-face-do-julgador-eprova-enadmissivel/>. Acesso em: 15 set. 2016.

GOLDBERG, Stephen. The Mediation of Grievances under a Collective Bargaining Contract: an alternative do arbitration. 77 Nw. U. L. Rev. 270, 1982. p. 281-305 In: RISKIN, Leonard L. \& WESTBROOK, James E. Dispute Resolution Lawyers. 2a ed. Saint Paul: West Group, 2004.

GOMES, Orlando. Contratos. $18^{\circ}$ ed. Atualizada e anotada por Humberto Theodoro Júnior. Rio de Janeiro: Forense, 1998.

GRINOVER, Ada Pellegrini. O minissistema brasileiro de Justiça consensual: compatibilidades e incompatibilidades. Publicações da Escola da AGU. v. 8. n. 1. jan./mar. 2016. Disponível em: $<$ http://dirittoetutela.uniroma2.it/files/2013/03/Origens-eevolu\%C3\%A7\%C3\%A3o.pdf>. Acesso em: 20 out. 2016. 
GROSMAN, Claudia Frankel \& BAYER, Sandra Regina Garcia Olivan. As Oportunidades da aplicação da Mediação no Âmbito Empresarial. Mediação de Conflitos para Iniciantes, Praticantes e Docentes. Parte II. Cap. 1.3, 2016. p. 388 apud. LEVY, Fernanda Rocha Lourenço. Cláusulas Escalonadas - A Mediação Comercial no Contexo da Arbitragem. São Paulo: Editora Saraiva, 2013.

GROSMAN, Claudia Frankel \& BAYER, Sandra Regina Garcia Olivan. As Oportunidades da aplicação da Mediação no Âmbito Empresarial. In: PELAJO, Samantha et al.. (Coord.). Mediação de Conflitos para Iniciantes, Praticantes e Docentes. Parte II. Cap. 1.3. Salvador: Ed. JusPodvim, 2016.

HALE, Durval et al.. O marco legal da mediação no Brasil. São Paulo: Editora Atlas, 2015.

HALE, Durval et al.. O marco legal da mediação no Brasil. São Paulo: Editora Atlas, 2015 In: CHASE, Oscar, G. I metodi alternativi di soluzione dele controversie e la cultura del processo: il caso degli Stati Uniti D'America. In: VARANO, Vincenzo (Org.). L'altragiustizia: il metodi alternativi di soluzione dele controversie nel diritto comparato. Milano: Giuffrè, 2007.

HALE, Durval et al.. O Marco Legal da Mediação no Brasil: Comentários à Lei no 13.140, de 26 de junho de 2015. $1^{\text {a }}$ ed. São Paulo: Atlas, 2016.

Íntegra do Recurso Especial $n^{o}$ 1.189.050/SP. Disponível em: $<$ http://www.adambrasil.com/wpcontent/uploads/2016/03/resp1189050sp_stj.pdf>. Acesso em: 20 out. 2016.

KREIDEL, Mark \& BIAZI, João Pedro. O Novo Regime Jurídico da Cláusula de Mediação. Levy \& Salomão Advogados. São Paulo, 30 jul. 2016. Disponível em:

<http://www.levysalomao.com.br/publicacoes/Boletim/novo-regimejuridico-da-clausula-de-mediacao>. Acesso em: 17 out. 2016.

LEVY, Fernanda Rocha Lourenço. Arbitragem, mediação e a cláusula escalonada. Jornal Carta Forense, 2014. Disponível em: < http://www.cartaforense.com.br/conteudo/entrevistas/arbitragemmediacao-e-a-clausula-escalonada/13774>. Acesso em: 10 out. 2016.

LIMA, Antonio Vanderler de. A integração entre a sistemática de resolução de conflitos e o novo Código de Processo Civil. Editora JC. 20 jul. 2016. Disponível em: <http://www.editorajc.com.br/2016/07/aintegracao-entre-a-sistematica-de-resolucao-de-conflitos-e-o-novo-codigode-processo-civil/>. Acesso em: 20 set. 2016. 
MARQUES, Claudia Lima. Contratos no Código de Defesa do Consumidor. Revista dos Tribunais, 1992.

MEURER, Zuleica Maria. Mediação: uma proposta de solução de conflitos a ser implantada no Brasil. Âmbito Jurídico. 30 jun. 2008. Disponível em: $<$ http://www.ambitojuridico.com.br/site/index.php?n_link=revista_artigos_leitura\&artigo_id=2 987>. Acesso em: 15 abr. 2016.

MITIDIERO, Daniel. Colaboração no Processo Civil - Pressupostos Sociais, Lógicos e Éticos, $2^{\mathrm{a}}$ ed. São Paulo: Revista dos Tribunais, 2011.

MOTTA JR, Aldemar de Miranda. Manual de Mediação de Conflitos para Advogados. Brasília-DF: Ministério da Justiça, 2014.

PANTOJA, Fernanda Medina \& OLIVEIRA, Marcello. Regulamentação da Mediação de Conflitos: Código de Ética In: PELAJO, Samantha et al.. (Coord.). Mediação de Conflitos para Iniciantes, Praticantes e Docentes. Parte I. Cap. 19. Salvador: Ed. JusPodvim, 2016.

PINHO, Humberto Dalla Bernardina de \& PAUMGARTTEN, Michele Pedrosa. Mediação Obrigatória: Um oximoro jurídico e mero placebo para a crise do acesso à justiça. In: XXI ENCONTRO NACIONAL CONPEDI. Uberlândia, 2012. p. 414-437. Disponível em:

$<$ http://www.humbertodalla.pro.br/arquivos/mediacao_obrigatoria _conpedi.pdf $>$. Acesso em: 01 mai. 2014.

PINHO, Humberto Dalla Bernardina de. (org.). A Nova Lei de Mediação Brasileira Comentários ao Projeto de Lei $\mathrm{n}^{\circ} 7169 / 14$. Revista Eletrônica de Direito Processual. Ano 8. Volume Especial. Rio de Janeiro, 2014. Disponível em:

<https://www.academia.edu/8676991/Revista_Eletrônica_de_Direito_Proce ssual_REDP_A_NOVA_LEI_DE_MEDIAÇÃO_BRASILEIRA_COME NTÁRIOS_AO_PROJETO_DE_LEI_N_7.16914>. Acesso em: 03 mai. 2016.

PINHO, Humberto Dalla Bernardina de. (org.). A Nova Lei de Mediação Brasileira Comentários ao Projeto de Lei $\mathrm{n}^{\circ} 7169 / 14$. Revista Eletrônica de Direito Processual. Ano 8. Volume Especial. Rio de Janeiro, 2014. Disponível em:

<https://www.academia.edu/8676991/Revista_Eletrônica_de_Direito_Proce ssual_REDP_A_NOVA_LEI_DE_MEDIAÇÃO_BRASILEIRA_COME NTÁRIOS_AO_PROJETO_DE_LEI_N_7.16914>. Acesso em: 03 mai. 2016 apud CHIARLONI, Sergio. I meccanismi conciliativi. São Paulo: Revista dos Tribunais, 2012. 
PINHO, Humberto Dalla Bernardina de. (org.). A Nova Lei de Mediação Brasileira Comentários ao Projeto de Lei ${ }^{\circ} 7169 / 14$. Revista Eletrônica de Direito Processual. Ano 8. Volume Especial. Rio de Janeiro, 2014. Disponível em:

$<$ https://www.academia.edu/8676991/Revista_Eletrônica_de_Direito_Proce ssual_REDP_A_NOVA_LEI_DE_MEDIAÇÃO_BRASILEIRA_COME NTÁRIOS_AO_PROJETO_DE_LEI_N_7.16914>. Acesso em: 03 mai. 2016 apud PINHO, Humberto Dalla Bernardina de \& PAUMGARTTEN, Michele Pedrosa. A institucionalização da mediação é a Panacea para o acesso à justiça?. Disponível em:

<http://www.publicadireito.com.br/artigos/?cod=0fd4b8a8354a77a3>.

Acesso em: 31 jul. 2014.

PINHO, Humberto Dalla Bernardina de. A Nova Lei de Mediação Brasileira Comentários ao Projeto de Lei n 7169/14. Revista Eletrônica de Direito Processual. Ano 8. Volume Especial. Rio de Janeiro, 2014. Disponível em:

$<$ https://www.academia.edu/8676991/Revista_Eletrônica_de_Direito_Proce ssual_REDP_A_NOVA_LEI_DE_MEDIAÇÃO_BRASILEIRA_COME NTÁRIOS_AO_PROJETO_DE_LEI_N_7.16914>. Acesso em: 03 mai. 2016 apud ANDREWS, Neil. Mediação e arbitragem na Inglaterra. São Paulo: Revista dos Tribunais, 2012.

SALES, Lilia Maia de Morais. Justiça e mediação de conflitos. Belo Horizonte: Del Rey, 2003.

SPENGLER, Fabiana Marion. Da Jurisdição à mediação: por uma outra cultura no tratamento de conflitos. Ijuí: Unijuí, 2010.

TARTUCE, Fernanda. Mediação nos conflitos civis. $3^{\mathrm{a}}$ ed. ver. atual e ampl. Rio de Janeiro: Forense. São Paulo: Método, 2016. p. 322 apud BRAGA NETO, Adolfo. A Mediação de conflitos nas organizações. Valor Econômico, São Paulo. Cad. E2., 8 out. 2004.

TARTUCE, Fernanda. Mediação nos conflitos civis. $3^{\mathrm{a}}$ ed. ver. atual e ampl. Rio de Janeiro: Forense. São Paulo: Método, 2016. p. 321 apud WATANABE, Kazuo. Cultura da sentença e cultura da pacificação. p. 685. In: YARSHELL, Flávio Luiz; MORAES, Maurício Zanoide de. (Coord.). Estudos em homenagem à professora Ada Pellegrini Grinover. São Paulo: DPJ, 2005.

TARTUCE, Fernanda. Mediação nos conflitos civis. $3^{\mathrm{a}}$ ed. ver. atual e ampl. Rio de Janeiro: Forense. São Paulo: Método, 2016. 
VOLPI NETO, Angelo. Cláusula Compromissória de Mediação em Contratos. Recivil. Disponível em:

<http://www.recivil.com.br/noticias/noticias/view/artigo-clausula-demediacao-por-angelo-volpi-neto.html>. Acesso em: 23 out. 2016. 